\title{
ValpoScholar
}

Valparaiso University Law Review

Volume 52

Number 1 Fall 2017

pp.19-64

\section{Fall 2017}

\section{The Complicated Business of State Supreme Court Elections: An Empirical Perspective}

\author{
Michael Heise \\ Cornell University
}

Follow this and additional works at: https://scholar.valpo.edu/vulr

Part of the Law Commons

\section{Recommended Citation}

Michael Heise, The Complicated Business of State Supreme Court Elections: An Empirical Perspective, 52 Val. U. L. Rev. 19 (2017).

Available at: https://scholar.valpo.edu/vulr/vol52/iss1/3

This Monsanto Lecture is brought to you for free and open access by the Valparaiso University Law School at ValpoScholar. It has been accepted for inclusion in Valparaiso University Law Review by an authorized administrator of ValpoScholar. For more information, please contact a ValpoScholar staff member at scholar@valpo.edu. 


\title{
MONSANTO LECTURE
}

\section{THE COMPLICATED BUSINESS OF STATE SUPREME COURT ELECTIONS: AN EMPIRICAL PERSPECTIVE}

\author{
Michael Heise*
}

\begin{abstract}
Proponents of judicial elections and related campaign activities emphasize existing First Amendment jurisprudence as well as similarities linking publiclyelected state judges and other publicly-elected state officials. Opponents focus on judicial campaign contributions' corrosive effects, including their potential to unduly influence judicial outcomes. Using a comprehensive data set of 2,345 business-related cases decided by state supreme courts across all fifty states between 2010-12, judicial election critics, including Professor Joanna Shepherd, emphasize the potential for bias and find that campaign contributions from business sources to state supreme court judicial candidates corresponded with candidates' pro-business votes as justices. While Shepherd's main findings generally replicate, additional (and alternative) analyses introduce new findings that raise complicating wrinkles for Shepherd's strong normative claims. Findings from this study illustrate that efforts to influence judicial outcomes are not the exclusive domain of business interests. That is, judicial campaign contributions from non- (and anti-) business interests increase the probability of justices' votes favoring non-business interests. As a result, critiques of judicial elections cannot properly rely exclusively on the influence of business interests. Moreover, that both business and non-business interests can successfully influence judicial outcomes through campaign contributions point in different (and possibly conflicting) normative directions. On the one hand, even if one agrees that the judicial branch qualitatively differs from the political and executive branches in terms of assessing campaign contributions' proper role, that the potential to influence judicial outcomes is available to any interest group (willing to invest campaign contributions) complicates popular critiques of judicial elections. On the other hand, the same empirical findings also plausibly strengthen critiques of judicial elections, especially for those who view the judicial domain differently than other political domains.
\end{abstract}

Professor, Cornell Law School. This Article is the written version of the Monsanto Lecture, delivered at Valparaiso University Law School on February 16, 2017. Joanna Shepherd, Dawn M. Chutkow, Nicole A. Heise, and Nicholas Stephanopoulos provided helpful comments on earlier drafts of this paper. 


\section{INTRODUCTION}

Debates over state judicial selection methods have persisted over time and increased in ferocity. ${ }^{1}$ Questions about how best to reconcile two desired goals reside at the core of such debates: judicial independence from and accountability to those bound by court rulings. Conventional wisdom typically links judicial appointments with enhanced independence and judicial elections with enhanced accountability. ${ }^{2}$ Among an array of selection methods, many states select their supreme court justices through popular election and some have done so since the mid-nineteenth century. ${ }^{3}$ While motivations for those states that use popular election as a judicial selection model vary, the motivations include a general impulse to increase judges' accountability to the people whom their decisions influence. ${ }^{4}$

States opting for judicial elections invariably confront important campaign finance questions for judicial candidates. ${ }^{5}$ As Professor Kritzer observes, " $[\mathrm{t}]$ he elephant in the room regarding the impact of judicial elections on judicial decisions is the question of whether judges who must stand for election ... are influenced by campaign contributions." 6 Legal contests over elections and campaign spending have forced the Supreme Court to consider the potentially corrosive effects of money in the electoral process and, within the bounds of the First Amendment, how concerns about corruption might be addressed. ${ }^{7}$ Similar and concurrent litigation over state judicial elections and campaign spending has imposed upon the Court derivative questions about whether its concerns about the role of money in elections must shift when the elected public official is a judge. ${ }^{8}$

\footnotetext{
1 See Jed H. Shugerman, Introduction to The PeOple's Courts: PURSUing Judicial INDEPENDENCE IN AMERICA (Cambridge, MA: Harvard University Press, 2012) (discussing the history of judicial selection methods within the states).

$2 \quad$ See id. at 6 (providing a link between judicial appointment and accountability as described by Alexis de Tocqueville).

See, e.g., id. at Ch. 3 (giving a helpful summary of the state's judicial selection process). Id.

See generally Herbert M. Kritzer, Impact of Judicial Elections on Judicial Decisions, 12 ANN. REV. L. SOC. SCI. 353, 364 (2016) (showing the impacts of campaign contributions on judicial decisions and providing evidence of direct and indirect influences).

$6 \quad I d$.

7 See, e.g., Citizens United v. Fed. Election Comm'n, 130 S. Ct. 876, 903 (2010) (considering concerns about electoral corruption). See also Buckley v. Valeo, 424 U.S. 1, 104-05, 107-08 (1976) (striking down campaign expenditure limits).

8 See, e.g., Williams-Yulee v. Florida Bar, 135 S. Ct. 1656, 1662 (2015) (upholding limits on judicial candidates' ability to personally solicit campaign funds). See also Caperton v. A.T. Massey Coal Co., 556 U.S. 868, 872 (2009) (showing that due process requires recusal when a judicial candidate receives contributions in excessive amounts); Republican Party of
} 
Even those not particularly bothered in the abstract by submitting judicial candidates (along with judges seeking retention) to the electoral process understand that the interaction between campaign spending and judicial elections heightens potential tensions. ${ }^{9}$ While early judicial elections may have been comparatively inexpensive affairs, judicial elections today, by contrast, are frequently quite expensive. ${ }^{10}$ As a result of a transformation of campaign spending and its role in judicial elections, "judges spend significant amounts of time and energy raising money." 11 As judicial campaign spending increased, the number of campaign contributors increased which, in turn, increased the probability that an elected judge would hear a case involving litigants (or attorneys) who contributed to presiding judges' campaigns. ${ }^{12}$ How one understands these tensions frequently pivots largely on one's own perspective. Where some see modern trends in judicial elections as "healthy," others increasingly see "nightmarish" problems. ${ }^{13}$

These latent tensions frequently emerge in a judicial election context that features pro- or anti-business campaign spending invested with an eye toward judicial engagement with existing or contemplated tort reform legislation. Writing about the 1980s, judicial election scholars noted an emergence of a "new-style" of state supreme court campaigns that increasingly resembled traditional political campaigns in tone, content, and methods. ${ }^{14}$ These same political scientists noted how judicial campaigns began to reach and engage voters on even the "more prosaic issues such as tort law."15 More to the point, "tort reform," a persistent flash-point for pro- and anti-business interests and, consequently, an

Minnesota v. White, 536 U.S. 765, 788 (2002) (concluding that the announce clause in the canon of judicial conduct violates the First Amendment).

9 See Citizens United, 130 S. Ct. at 961 (describing how campaign spending can fuel corruption or the appearance of corruption). See also Williams-Yulee, $135 \mathrm{~S}$. Ct. at 1659-60 (examining how campaign contributions in judicial elections can jeopardize judiciary integrity).

10 See Dmitry Bam, Recusal Failure, 18 N.Y.U. J. LEGIS. \& PUB. POL’y 631, 638 (2015) (describing the increase in spending on judicial elections).

$11 \quad$ Id.

12 See id. (highlighting an example in which two-thirds of the cases heard by the Pennsylvania Supreme Court between 2008-09 had a campaign contributor as the party, lawyer, or law firm).

13 See David Schultz, Minnesota Republican Party v. White and the Future of State Judicial Selection, 69 ALB. L. REV. 985, 985 (2006) (describing how the future of judicial elections, such as in Texas, may be nightmarish considering its increased politicization).

14 See, e.g., Marie Hojnacki \& Lawrence Baum, "New Style" Judicial Campaigns and the Voters: Economic Issues and Union Members in Ohio, 45 WEST. POL. QUART. 921, 922 (1992) (noting the emergence of the "new style" of judicial elections in which candidates are more likely to incorporate policy into their campaigns).

$15 \quad I d$. at $944-45$. 
important political issue in many states, is "fought not only in state legislatures but also in state supreme courts." 16 Professors Kang and Shepherd characterize tort reform issues as business contributors' "primary focus in state judicial races." ${ }^{17}$ One predictable consequence in states that elect judges is that "much of the money contributed in judicial races tends to be given by those interested in the shape of tort law."18

While acknowledging that "any interest group might exert influence over the judiciary," Kang and Shepherd's work focuses on the influence of pro-business judicial campaign contributions on judicial votes in business cases. ${ }^{19}$ Professors Kang and Shepherd attribute their focus on business' potential influence on judicial outcomes to the business lobby's unique ability to do so. This study seeks to broaden Kang and Shepherd's focus by exploring the possible influence of non- (and anti-) business contributions as well.

Whether judicial campaign contributions influence judicial votes and case outcomes is, at one crucial level, an empirical question. In contrast, how best to characterize publicly-elected judges and their non-judicial elected counterparts is better understood as a normative question. To a large degree, how one understands a publicly-elected state judge's function informs one's assessments about judicial elections and judicial campaign spending. Proponents of judicial elections, such as Professor Hall, emphasize the similarities that link elected state supreme court justices and other elected officials. ${ }^{20}$ For critics of judicial elections, however, this is precisely the problem. Specifically, for many judicial election critics the similar ways in which campaign spending influences judicial, legislative, and executive elected officials contribute to problems with judicial elections because of the potentially fundamental ways in which the judicial branch differs from the legislative and executive branches. ${ }^{21}$ Consequently, many of the arguments that distinguish

\footnotetext{
16 Anthony Champagne, Tort Reform and Judicial Selection, 38 LOY. L.A. L. REV. 1483, 1488 (2005).

17 Michael S. Kang \& Joanna M. Shepherd, The Partisan Price of Justice: An Empirical Analysis of Campaign Contributions and Judicial Decisions, 86 N.Y.U. L. REV. 69, 85 (2011).

18 See Champagne, supra note 16, at 1488 ("[i]t is state judge selection that produces the major battles between economic interests that are concerned with a state's tort law").

19 Kang \& Shepherd, supra note 17, at 85.

20 See Melinda G. Hall, AtTACKING Judges: How CAMPAign Advertising Influences STATE SuPREME COURT EleCtIONS 126 (Stanford University Press, 2015) (discussing how studying supreme court elections is essential to understanding the relationship between campaign contributions and judicial votes).

21 See, e.g., Michael S. Kang \& Joanna M. Shepherd, Judging Judicial Elections, 114 MiCH. L. REV. 929, 930 (2016) (addressing how the similarities between state supreme court elections and elections in other offices are why critics believe a problem exists). But see James Sample, Democracy at the Corner of First and Fourteenth: Judicial Campaign Spending and Equality, 66
} 
campaign spending in the judicial and non-judicial electoral contexts pivot on distinguishing publicly-elected state judges from other publiclyelected officials. ${ }^{22}$

Even the U.S. Supreme Court appears genuinely conflicted over how to frame elected judicial actors in the campaign context. ${ }^{23}$ On the one hand, in striking down a Minnesota law limiting judicial candidates' political speech, the Court implicitly recognized the First Amendment's similar purchase when it came to pure political speech, whether in the judicial, legislative, or executive electoral contexts. ${ }^{24}$ In so doing, the White decision in 2002 emphasizes the Court's implicit recognition of similarities between publicly-elected judges and the non-judicial counterparts. ${ }^{25}$

In 2015, however, the Court upheld a Florida prohibition on a judicial candidate's direct campaign fundraising solicitations. ${ }^{26}$ In contrast to the White decision, the Williams-Yulee decision suggests that the Court (or at least five Justices) views judicial candidates differently than other political candidates. ${ }^{27}$ Specifically, while the White opinion implicitly frames judicial candidates as functionally equal to other political candidates for purposes of free speech protections, the Williams-Yulee opinion, by contrast, takes another tact by endeavoring to distinguish publicly-elected state judges from other publicly-elected officials in the campaign contributions' context. ${ }^{28}$ The Court's effort to restrict judicial candidates' fundraising in Williams-Yulee rests uneasily with the Court's prior decision in Buckley where it functionally construed campaign contributions and spending as core political speech. ${ }^{29}$ Indeed, critics of the Williams-Yulee

N.Y.U. ANN. SURV. AM. L. 727, 756-57 (2011) (arguing that differences in democratic expectations in the courts and traditional political arenas justify treating campaign spending in judicial elections differently than in political elections).

22 See generally Republican Party of Minnesota v. White, 536 U.S. 765, 797 (2002) (Justice Stevens dissenting) (describing judges and public officials' differing roles).

23 Compare Williams-Yulee v. Florida Bar, 135 S. Ct. 1656, 1659 (2015) (upholding limits on judicial candidates' ability to personally solicit campaign funds), with White, 536 U.S. at 774 (explaining that the announce clause in the canon of judicial conduct violates the First Amendment).

24 See White, 536 U.S. at 783-84 (holding that Minnesota cannot prohibit judicial candidates from announcing their views on legal and political issues).

${ }_{25}$ See id. at 787-88 (comparing the First Amendment election rights of judges with those of their non-judicial counterparts).

26 See Williams-Yulee, 135 S. Ct. at 1673 (reasoning that when a state has an interest in preserving public confidence in the judiciary the state can adopt narrowly tailored restrictions to a judicial candidate's solicitations).

27 See id. at 1662 ("Judges are not politicians, even when they come to the bench by way of the ballot.").

28 See, e.g., id. (holding that the First Amendment does not preclude all restrictions on judicial solicitation of campaign funds). See also White, 536 U.S. at 773 (opining that the announce clause is not tailored to serve many interests).

29 See Buckley v. Valeo, 424 U.S. 1, 14 (1976) (striking down campaign expenditure limits). 
decision quickly noted how the Court's analysis applies a "heavily watered-down version of strict scrutiny analysis" - particularly as it relates to the narrowly tailored prong - to enable the Court to reach its outcome yet maintain the outward appearance of having applied strict judicial scrutiny. ${ }^{30}$

At a conceptual level, the contested issues run even deeper. Whether elected state judges are, unlike their elected counterparts in the executive and legislative branches, charged with a counter-majoritarian function that is structurally threatened by judicial elections resides at the heart of what divides judicial election proponents and critics. Moreover, more recent Court decisions imply a growing unease with "protecting the integrity of the judiciary and maintaining the public's confidence in an impartial judiciary." 31 As well, the Court wants elected judges to steer clear of creating an appearance of impropriety within a constitutional regime that permits judicial candidate campaign speech and some forms of campaign fundraising. ${ }^{32}$ Finally, within a context noted for inevitably conflicting principles and impulses, it remains unclear whether the divide separating judicial election proponents and opponents can be bridged at all and, if it can, what role empirical scholarship might play in informing arguments.

Two likely causal pathways help explain relations between judicial campaign contributions and judges' votes that reflect contributors' interests. ${ }^{33}$ One includes selection bias for the sub-pool of candidates who prevail in their judicial elections. Specifically, prevailing judges may already possess a preference for (or against) business interests. Another, more subtle, causal mechanism involves judges who, while otherwise agnostic about business interests, may favor (or disfavor) business interests in their votes with an eye towards securing future campaign contributions in future judicial elections. While this study's data and research design are unable to identify which casual pathway might be salient, this study can assess whether and, if so, to what degree campaign contributions from business and non-business interests correlate with judges' votes in business cases.

The data set used in this study merges state supreme court decisions by 439 state supreme court justices in 2,345 concluded business-related cases decided between 2010-12 across all fifty states with information on

30 Noah B. Lindell, Comment, Williams-Yulee and the Anomaly of Campaign Finance Law, 126 YALE L.J. 1577, 1577 (2017).

31 Williams-Yulee, 135 S. Ct. at 1666 (internal citations and quotations omitted).

32 See id. at 1664 (explaining that an appearance of impropriety would prompt one to question a judge's impartiality).

33 See, e.g., Kang \& Shepherd, supra note 17, at 72 (discussing the two pathways that explain the relationship between judicial campaigns and votes). 
more than 175,000 contribution records that detail every reported contribution to every sitting state supreme court justice in each elected state supreme court justice's most recent election. Judicial campaign contributions to judges were categorized based on their source as representing a pro-business, non-business, or anti-business interest.

The central results from my initial analyses comport with Professor Shepherd's earlier findings about relations between judicial campaign contributions from pro-business interests and judges' pro-business votes. ${ }^{34}$ Additional analyses also identify a new, though related, finding: campaign contributions from non- (and anti-) business interests correlate with judges' anti-business votes. Evidence that non- and anti-business interests also correlate with desired judicial votes is important partly because it challenges Kang and Shepherd's critical assumption about business contributors' "unique" abilities when it comes to influencing judicial votes. ${ }^{35}$

The influence of non- and anti-business campaign contributions on judicial votes both challenges and complicates traditional critiques against judicial elections that focus on claims about business interests' undue influence. That is, evidence that business and non-business interests may successfully influence judicial outcomes through campaign contributions points in different (and possibly conflicting) normative directions. Even if one agrees that the judicial branch qualitatively differs from the political and executive branches in terms of assessing campaign contributions' proper role, that the potential to influence judicial outcomes is available to potentially any discrete interest group (willing to invest campaign contributions) dulls the dominant, business-centric public criticisms of judicial elections. Of course, findings from this study also plausibly strengthen critiques of judicial elections overall, especially from those who view the judicial domain as distinct from other political domains.

This Article proceeds in six parts. Part II briefly maps out the major judicial selection models in the United States for federal and state courts, as well as the broad legal terrain that structures contests arising out of the judicial campaign context. ${ }^{36}$ Part III summarizes the leading empirical work, with particular emphasis on Shepherd's 2013 paper that this study sets out to expand. The data and methodology are described in Part IV. Results are both presented and discussed in Part V. Part VI concludes.

\footnotetext{
34 See infra Part V.B (comparing results with Shepherd's earlier model that looked at the relations between judicial campaign contributions and judges' votes).

35 See Kang \& Shepherd, supra note 17, at 85 (discussing business groups' unique ability to influence judges).

36 See infra Part II (discussing judicial election variation and how judicial elections have changed over time).
} 


\section{JUdiCIAL SELECTION AND EVOLVING LEGAL TERRAIN}

While this paper focuses on empirical and normative issues raised by campaign contributions in state judicial elections, it remains important to note that alternative methods of judicial selection exist. Equally important is that the legal terrain shaping efforts to regulate judicial candidates' conduct and speech, as well as judges' conduct on the bench, continues to evolve over time.

\section{A. Judicial Selection Variation}

Many state judges are elected to the bench, and the mechanisms used by states range from partisan elections to non-partisan retention elections. The selection mechanism for Article III judges (and justices) in the federal context, by contrast, involves presidential appointment and Senate confirmation. ${ }^{37}$ Once commissioned, federal judges enjoy life tenure, subject only to impeachment for conduct that falls below "good behavior." 38 By removing federal judges' appointments from direct electoral processes and pressures, the Founders sought to better insulate federal judges from the ever-shifting political winds of the day, promote independent judgment, and, it is thought (indeed, perhaps even assumed), to enhance justice.

However, appointment-based (or even merit-based) judicial selection models are far from immune to criticisms. Despite important differences separating elective and appointive judicial models, the role of politics persists. Indeed, President Obama's effort to promote Judge Garland from the appeals court to the U.S. Supreme Court during the president's final year in office and many leading Republican senators' public declarations of their refusal to meet with any appointee so close to a general election have only renewed public focus and debate on judicial selection as well as politics' proper role. ${ }^{39}$ Setting aside separation of powers concerns and intra-branch rivalries, such debates imply that questions about the role of

\footnotetext{
37 U.S. CONST., art. II, § 2 .

38 U.S. CONST., art. III, § 1. See also Edward Lazarus, Life Tenure for Federal Judges: Should It Be Abolished?, CNN (Dec. 10 2004), http://www.cnn.com/2004/LAW/12/10/ lazarus.federal.judges/ [https://perma.cc/F7L9-5QLM] (showing that Americans' views on a judge's tenure are changing).

39 See Paul Callan, Paul Callan: The Best Republican Option?, CNN (Mar. 17, 2016), http://www.cnn.com/2016/03/16/opinions/merrick-garland-supreme-court-obamaopinion-roundup/index.html [https://perma.cc/57P8-T5D4] (explaining why the Republicans refused to meet with any appointee so close to a presidential election).
} 
politics when it comes to selecting judges, even appointed judges, persist. 40

It has become received political rhetoric that "unelected" federal judges make decisions that inform public life and shape the polity in critical ways. To be sure, direct access to judicial selections by those bound by judicial decisions - through direct or retention elections - simply does not exist in the federal sphere. Moreover, one critical constitutional check on federal judges, impeachment, has been invoked only rarely and typically incident to some of the more egregious cases of judicial misconduct. ${ }^{41}$

However, citizens are afforded some ability to pick their brand of justice through their participation in presidential and congressional elections. ${ }^{42}$ Indeed, with the Robert Bork hearings serving as something of a political watershed moment, subsequent presidential political campaigns have often featured promises about what kind of judges (and justices) the candidate would nominate if elected. ${ }^{43}$ Similar campaign rhetoric is heard in senatorial campaigns as well. Thus, even in the federal judicial space, while perhaps only indirectly, citizens nonetheless possess some degree of influence over the selection of judges.

In addition, empirical assertions about the comparative advantages (or disadvantages) of an elected judiciary are advanced too often as if counterfactual data do not exist. How various states select state supreme court justices, however, supplies quite helpful, if imperfect, variation. While federal judge selection excludes any direct electoral component, judge selection methods across the fifty states vary considerably and, important to this study, include judicial elections. ${ }^{44}$

Scholarly attention to state courts and state judge selection is warranted in its own right as more than ninety percent of the nation's

\footnotetext{
40 See Kang \& Shepherd, supra note 17, at 125-26 (depicting how politics will always have a crucial role in judicial elections).

41 See, e.g., Raoul Berger, Impeachment of Judges and "Good Behavior" Tenure, 79 YALE L.J. 1475, 1507 (1970) (noting that impeachment is only used in very serious cases involving judicial misbehavior).

42 See generally ROBERT A. DAHL, HOW DEMOCRATIC Is THE AMERICAN CONSTITUTION? 73, 78 (Yale University Press, Nota Bene ed. 2001) (describing the democratic process and how people can elect leaders that reflect their opinions).

43 See Nina Totenberg, Robert Bork's Supreme Court Nomination Changed Everything, Maybe Forever, NPR (Dec. 12, 2012), http://www.npr.org/sections/itsallpolitics/2012/12/19/ 167645600 /robert-borks-supreme-court-nomination-changed-everything-maybe-forever [https://perma.cc/REH2-UDTG] (explaining the partisan divide resulting from Bork's failed Supreme Court nomination).

$44 \quad$ See Kang \& Shepherd, supra note 17, at 76-77 (stating that judge selection methods differ considerably across the country).
} 
judicial work is performed in state courts, ${ }^{45}$ and approximately ninety percent of all state court judges (and state supreme court justices) participate in some form of direct electoral activity. ${ }^{46}$ Insofar as campaign contributions remain one form of constitutionally-protected core political speech, albeit a regulated one, it is not surprising (indeed, inevitable) that state judicial candidates attract campaign funding.

What might surprise some, however, is how the magnitude of campaign spending in state judicial elections has increased over time, particularly since the 1980s. ${ }^{47}$ As Professors Kang and Shepherd note, since "money buys things," questions about what judicial campaign contributions might be "purchasing" warrant close attention. ${ }^{48}$ Various threats posed by judicial campaign contributions to the fair administration of justice (or even the appearance of fairness) have been considered in detail by others. ${ }^{49}$ After exploring the efficacy of "purchasing" judicial outcomes in the state context from an empirical perspective, this Article goes on to consider whether the state judicial experience differs in material ways from efforts to influence judicial selection in the federal context.

At this juncture it is important to make clear what this Article does not consider. I take as a given that judicial canons, state rules, norms, etc., correctly regulate against any judicial misconduct, which would include any judge who bases a legal decision or ruling exclusively in response to a judicial campaign contribution. ${ }^{50}$ Such activity offends any fair-minded understanding of what justice might mean. Moreover, I also assume that a well-functioning judicial recusal doctrine, despite its limitations, provides one important instrument that can reduce conflicts between a judge's private interests and the administration of impartial justice. By pushing to one side efforts to, quite literally, "purchase" a judge (or a judicial outcome) through judicial campaign contributions, I focus instead on the empirical and normative contours of the more granular and nuanced constituent efforts to "purchase" a judicial philosophy or perspective through judicial campaign contributions.

\footnotetext{
45 See, e.g., Shirley S. Abrahamson, The Ballot and the Bench, 76 N.Y.U. L. REV. 973, 976 (2001) (examining the variety of judicial elections and that most state court judges are elected).

46 See Roy A. Schotland, New Challenges to States' Judicial Selection, 95 GEO. L.J. 1077, 1091 (2007) (app. 2) (stating that "over 90 percent of judges reach the bench by appointment to fill vacancies").

47 See id. at 1079-80 (describing campaign spending since the 1980's, which have evolved due to changes in advertising techniques).

48 Michael S. Kang \& Joanna M. Shepherd, The Partisan Foundations of Judicial Campaign Finance, 86 SO. CAL. L. REV. 1239, 1240 (2013).

49 See, e.g., SHUGERMAN, supra note 1 (showing the different views on judicial contribution funding).

50 See, e.g., id. (describing the assumptions involved in his analysis).
} 


\section{B. Judicial Elections' Evolving Legal Terrain}

Understanding how the interaction between campaign spending and judicial elections heightens potential tensions requires an understanding of relevant (and evolving) legal doctrines in this particular context. The relevant doctrines include those relating to the First Amendment and campaign speech and spending and, more recently, how judicial campaign contributions implicate a judge's recusal obligations.

The Supreme Court's Buckley v. Valeo ${ }^{51}$ decision in 1976, construing political campaign contributions and expenditures as core political speech (although allowing for regulations on contributions), continues to wield important influence. In 2002, the Court explored the contours of core political speech rights in the judicial electoral context. ${ }^{52}$ In White, the Court struck down a Minnesota Supreme Court canon of judicial conduct that prohibited candidates seeking elected judicial office from "announc[ing] his or her views on disputed legal or political issues" on First Amendment grounds. ${ }^{53}$

Writing for the Court, Justice Scalia began by noting that strict judicial scrutiny was warranted as the Minnesota canon sought a content-based speech restriction that implicated the First Amendment's core. ${ }^{54}$ While conceding the state's interest in the impartial administration of justice as well as in promoting its appearance may well be "compelling," the Court nonetheless concluded that the speech restriction was not sufficiently narrowly tailored. ${ }^{55}$ The Court also noted that the Minnesota judicial canon itself separately treated efforts by judicial candidates to announce their particular views on legal issues from candidates' efforts to "pledge or promise" to deliver specific judicial outcomes upon election to the bench. ${ }^{56}$ While the White opinion expressly side-steps any resolution involving the latter issue, ${ }^{57}$ the Court's acknowledgement of it hints at deeper and more uncomfortable complexities.

Nested within the Court's opinion, however, and expressly engaged by the dissenting Justices, is the assumption that "judicial candidates should have the same freedom 'to express themselves on matters of

51 See 424 U.S. 1, 143 (1976) (striking down campaign expenditure limits).

52 See Republican Party of Minn. v. White, 536 U.S. 768, 768 (2002) (analyzing the constitutionality of the Minnesota judicial canon's attempt to prevent judicial candidates from announcing their views on certain issues).

53 See id.

54 See id. at 774 (stating that the Court of Appeals properly decided that strict scrutiny was the proper test to determine the constitutionality of the speech restriction).

55 See id. at 788.

56 See id. at 770 (explaining Minnesota's judicial canon).

57 See id. (determining that the court "express[ed] no view" on the issue of promising particular judicial outcomes). 
current public importance' as do all other elected officials." 58 That is, while five Justices implicitly refused to analytically distinguish judicial candidates from candidates for other publicly-elected offices, at least four dissenting Justices advanced such a distinction, noting "the critical difference between the work of the judge and the work of other public officials." 59 To the dissenting Justices, their impulse that "[j]udges are not politicians" 60 carried over to those state judges and justices who must submit themselves to the political processes and the electorate.

Having decided that political campaign contributions and spending constitute core political speech in Buckley and that state judicial candidates were free to engage with contested legal and political issues in White, in 2009 the Supreme Court was asked to speak directly to some practical problems posed by judicial campaign contributions, specifically how an elected judge's campaign contributions implicated recusal obligations. ${ }^{61}$ In Caperton, the Supreme Court recognized for the first time Due Process concerns arising out of the potential for judicial bias flowing from campaign contributions from a litigant appearing before a judge who was the recipient of financial support from that litigant. ${ }^{62}$ While Caperton is technically a "recusal" case, the salient facts make clear its relevance to the challenges arising out of campaign contributions to judges running for election to the bench.

The key facts in Caperton are both straightforward and compelling. ${ }^{63}$ In 1998, Harmon Mining Company successfully sued A.T. Massey Coal Company for a contract breach. ${ }^{64}$ In 2002, A.T. Massey Coal Company appealed the $\$ 50$ million trial court verdict favoring Harmon Mining. ${ }^{65}$ Between the trial court decision and a subsequent appeal to West Virginia's Supreme Court, Don Blankenship, Massey Coal Company's CEO, spent \$3 million in 2004 to help ensure Brent Benjamin's election to

\footnotetext{
58 See Republican Party of Minn. v. White, 536 U.S. 768, 797 (2002) (Stevens, J., Souter, J., Ginsburg, J., and Breyer, J., dissenting).

59 Id. at 798 . See also id. at 797 (explaining the rationale behind the dissent of the four Justices).

60 See id. at 821 (critiquing the dissent's reasoning).

61 See Caperton v. A.T. Massey Coal Co., Inc., 556 U.S. 868, 872 (2009).

62 See id. at 889-90 (concluding that application of the Due Process Clause will only be confined to rare instances).

63 See, e.g., JOHN GRISHAM, THE APPEAL (Doubleday, 1st ed. 2008) (citing the relationship between the book THE APPEAL and the Caperton case). Indeed, while formally set in a fictitious Mississippi town, it is likely that the political and legal controversy surrounding the Caperton case provided some inspiration for the 2008 best-selling novel. Id.

64 See Chris Dickerson, Caperton-Massey Saga (Mar. 29, 2012), https://wvrecord.com/ stories/510601919-caperton-massey-saga [https://perma.cc/74DE-FDKG] (describing the procedural history of the Caperton case).

65 See id. (describing A.T. Massey's appeal of the $\$ 50$ million adverse verdict).
} 
the West Virginia Supreme Court. ${ }^{66}$ Four years after his election to the West Virginia Supreme Court, Justice Benjamin refused calls for his recusal from hearing and participating in A.T. Massey's appeal. ${ }^{67}$ Not only did he refuse recusal motions, but on two separate occasions Justice Benjamin joined a 3-2 majority that ruled in favor of A.T. Massey and reversed the original $\$ 50$ million trial verdict. ${ }^{6}$ Harmon Mining Company then appealed to the U.S. Supreme Court, arguing that Justice Benjamin's participation was improper.

The U.S. Supreme Court agreed with Harmon Mining and, writing for the Court, Justice Kennedy's opinion emphasizes the pending litigation that coincided with the timing of Blankenship's significant campaign contribution to (now) Justice Benjamin as well as Blakenship's personal financial interest in a favorable disposition of the A. T. Massey case. ${ }^{69}$ As a consequence, Justice Kennedy concluded that, in such a circumstance, Justice Benjamin should have recused himself from participating in the Massey litigation due to an unacceptable "probability of bias" which constituted a threat to the Constitution's Due Process Clause. ${ }^{70}$

In a vigorous dissent, Justice Roberts emphasized the uncertainty that necessarily flows from the Court's departure from two clear situations that require a judicial recusal: "[w]hen the judge has a financial interest in the outcome of the case, and when the judge is trying a defendant for certain criminal contempts." 71 Justice Roberts voiced deep skepticism about judicial efforts to define when a "probability of bias" exists and, if it does, what specific probabilistic level warrants judicial recusal. ${ }^{72}$ To underscore his skepticism, Justice Roberts went on to list forty specific questions, many salient to the judicial campaign contribution context, which, in the minds of four dissenting justices, raise uncertainty about whether a judge should recuse under the guidance provided by the Court's Caperton decision. ${ }^{73}$ Owing to the increased uncertainty

66 See Caperton, 556 U.S. at 873 (describing Don Blankenship's campaign contributions to Brent Benjamin).

67 See id. at 873-74 (stating that Benjamin refused to recuse himself because there was no information that he would be "anything but fair and impartial").

68 See id. at 874-75.

69 See id. at 886 (addressing the reasons that Justice Benjamin should have recused himself from the case).

See id. at 887 (articulating a "probability of bias" recusal standard).

See id. at 890 (Roberts, C.J., dissenting).

See id. at 890-91 (indicating that the "probability of bias" standard is difficult to define in a coherent manner, thus making it unclear when recusal is constitutionally required).

73 See id. at 893-98 (citing a list of questions to consider when determining if recusal is necessary). 
surrounding judicial recusal created by the Caperton decision, Justice Roberts predicted a flood of recusal motions. ${ }^{74}$

Importantly, the Court's opinion and the dissents in Caperton implicitly assume an empirical relation between campaign contributions to judicial candidates and their subsequent votes as judges. On one level, such an assumption makes obvious - indeed, intuitive-sense. ${ }^{75}$ In the political realm, not only is such a relation between campaign contributions and political candidates assumed, but is frequently expected, if not demanded, by contributors. ${ }^{76}$

However, it is also important not to ignore complicating wrinkles in Caperton that are far less appreciated because they run against and cloud an admittedly compelling public narrative. While the Caperton litigation and events involving Massey Coal and West Virginia Supreme Court Justice Benjamin are often pointed to as an "easy" example of all that can go wrong with judicial elections, Justice Benjamin's actual voting record on cases involving the Massey Coal Company (and other, related, Massey Energy holdings) confounds the received public narrative. ${ }^{77}$ According to a West Virginia Supreme Court press release, prepared by that court's administrative office, during his initial four years on the Court, "Justice Benjamin voted against the [legal] interests of Massey Energy or its subsidiary 81.6 percent of the time."78 Before the Caperton litigation, in other cases that also involved Massey Coal none of the parties petitioned

\footnotetext{
74 See id. at 902 (warning that the result of the Court's decision could be a flood of litigation). It warrants note that, thus far, the scholarly consensus is that Chief Justice Robert's prediction of a flood of litigation activity stimulated by Justice Kennedy's opinion in Caperton has been largely unfulfilled. See, e.g., Bruce A. Green, Fear of the Unknown: Judicial Ethics After Caperton, 60 SYRACUSE L. REV. 229, 233 (2010) (stating that there has not been a flood of litigation after Caperton).

75 See id. at 1438 (analyzing the higher likelihood that a Republican judge would cast a partisan vote).

76 See Mark Schmitt, What if You Had as Much Political Influence as a Billionaire?, CNN (Feb. 16, 2015), http://www.cnn.com/2015/02/16/opinion/schmitt-politics-money/index.html [https://perma.cc/78CT-9CVY] (considering the increased ability of the wealthy to get political influence through large campaign donations).

77 See West Virginia State Supreme Court News, Summary of Chief Justice Benjamin's Dispositive Voting Record Regarding Massey Energy Cases from 01/01/2005 to 12/31/2008 (Mar. 31, 2009), http://www.courtswv.gov/public-resources/press/releases/2009-releases/ march2_09.htm [https:// perma.cc/E23F-PAW8] (outlining Justice Benjamin's voting history in Massey cases).

78 Id. The analysis of Justice Benjamin's Massey Energy-related voting record excludes votes on such non-dispositive matters as motions for time extensions, exceeding page limitations on briefs, etc. See id. (stating that the list of Justice Benjamin's voting record on cases involving Massey does not include any votes on non-dispositive matters). See also Roland D. Rotunda, Codifying Caperton v. A.T. Massey Coal Co., 42 MCGEORGE L. REV. 95, 103 (2010) (explaining Justice Benjamin's decisions on other cases involving Massey Energy).
} 
for Justice Benjamin's recusal. ${ }^{79}$ Thus, despite Justice Benjamin's complicated judicial voting record in cases involving Massey Energy (and Massey Coal company), the prevailing public narrative surrounding Justice Benjamin characterizes him (fairly or not) as having been "bought" by Blankenship to serve on the West Virginia Supreme Court on behalf of Massey Coal's interests. ${ }^{80}$

A more recent decision in Williams-Yulee further evidences the Court's growing wariness about and unease with practical implications flowing from elected judges. ${ }^{81}$ In Williams-Yulee, the Court upheld Florida's Code of Judicial Conduct which prohibits state judicial candidates from personally soliciting campaign funds. ${ }^{82}$ During her judicial campaign, Williams-Yulee sent a mass-mailing fundraising letter to potential contributors and then posted her letter to a campaign website. ${ }^{83}$ Although she lost her election, the Florida Bar initiated a disciplinary review, concluded that she violated Florida's Canon of Judicial Ethics, and fined Williams-Yulee \$1,860.30.84

Williams-Yulee challenged the Florida Canon of Judicial Ethics' prohibition of a judicial candidate's direct, personal solicitation of campaign funds on First Amendment grounds. While only a plurality of the Justices concluded that Florida's canon triggered traditional strict judicial scrutiny, the Court administered what at least one commentator has described as a "heavily watered-down version of strict scrutiny." 85 Concluding that the canon's goal of "protecting the integrity of the judiciary and maintaining the public's confidence in an impartial judiciary" was, indeed, a compelling interest, ${ }^{86}$ and that a restriction on personal solicitation activities so as to avoid an "appearance of

\footnotetext{
79 See, e.g., U.S. Steel Mining Co. v. Helton, 631 S.E.2d 559, 577 (W. Va. 2005) (upholding the constitutionality of several coal taxes Massey challenged). See also Helton v. Reed, 638 S.E.2d 160, 166 (W. Va. 2006) (reflecting Justice Benjamin's vote against Massey companies at the merits stage).

80 See Richard Gillespie, Buying a Judicial Seat for Appeal: Caperton v. A.T. Massey Coal Company, Inc., is Right Out of a John Grisham Novel, 30 J. NAT'L Ass'N ADMIN. L. JuDICIARY 309, 315 (2010) (advancing the argument that Justice Benjamin had been "bought" by Massey).

81 See Williams-Yulee v. Fla. Bar, 135 S. Ct. 1656, 1662 (2015) (upholding a Florida restriction on campaign contributions in judicial elections).

82 See id. at 1663 (stating that judicial candidates should not be allowed to personally solicit campaign contributions).

83 See id. (detailing Williams-Yulee's solicitation of campaign funds).

84 See id. at 1663-64 (explaining the application of Florida's Canon of Judicial Ethics Canon 7(C)(1) and Williams-Yulee's fine for violation). Florida's Code of Judicial Conduct, Canon 7(C)(1) resembles the American Bar Association's Model Code of Judicial Conduct.

85 See Lindell, supra note 30, at 1577 (criticizing the version of scrutiny the Court applied).

86 Williams-Yulee, 135 S. Ct. at 1666 (internal citations and quotations omitted).
} 
impropriety" was narrowly tailored, the Court went on to uphold Florida's Canon 7(C)(1). ${ }^{87}$

Setting aside the Court's specific application of the narrowly tailored prong analysis in Williams-Yulee, ${ }^{88}$ as a descriptive matter it remains accurate to note that when the Court applies traditional First Amendment doctrine - and the strict scrutiny test in particular - to campaign finance restrictions in the context of non-judicial elections, the results are complicated and mixed. For example, when it comes to non-judicial candidates' ability to fundraise or spend their own money, First Amendment rights typically prevail, though members of Congress are not permitted to solicit funds from their governmental offices. ${ }^{89}$ Despite this palpable trend, in applying these general principles to state judicial candidates, the Court departed somewhat from its usual path in WilliamsYulee. Notably, the Court appeared to diminish concerns about how Florida's Canon 7(C)(1) burdened judicial candidates' speech rights in an almost transparently self-conscious manner. ${ }^{90}$

The dissenters in Williams-Yulee rightly pointed out that Florida's Canon $7(C)(1)$ bans direct candidate financial solicitations in any form and to any person. ${ }^{91}$ That is, the Canon's prohibition is not necessarily limited to only those solicitations likely to create any appearance of impropriety. Florida's ban also applies even where those solicited might never have a legal interest in a case decided before the soliciting judicial candidate. ${ }^{92}$ Consequently, Williams-Yulee implies that the Court's concerns about the

\footnotetext{
87 See, e.g., Note, Freedom of Speech - Judicial Campaign Speech-Williams-Yulee v. Florida Bar, 129 HARV. L. REV. 231, 232 (2015) (critiquing of the Court's First Amendment analysis of regulations of judicial elections). Language in Florida's Canon 7(C)(1) resembles language in rules for federal appellate judges and justices. See also Code of Conduct for United States Judges, Canon 2 (Mar. 2014), http://www.uscourts.gov/sites/default/files/vol02a-ch02 0.pdf [https://perma.cc/AW65-3V5W] ("[a] judge should avoid impropriety and the appearance of impropriety in all activities").

88 See 135 S. Ct. at 1685 (Alito, J., dissenting) (describing Florida's Canon 7(C)(1) as "about as narrowly tailored as a burlap bag").

89 See Citizens United v. Fed. Election Comm'n, 130 S. Ct. 876, 898 (2010) (expressing that a prohibition on corporate expenditure violates the First Amendment). See also U.S. HOUSE of Representatives COMMITTEE ON Ethics, HOUSE Ethics MANUAL 132-35 (2008), https://ethics.house.gov/sites/ethics.house.gov/files/documents/2008_House_Ethics_M anual.pdf [https://perma.cc/82ZD-LX75] [hereinafter HOUSE ETHICS MANUAL] (providing that, generally, solicitation of funds from governmental offices is prohibited).

90 See Williams-Yulee, 135 S. Ct. at 1670 (finding that Florida's Canon 7(C)(1) does not burden judicial candidates' speech rights).

91 See id. at 1679 (Scalia, J., dissenting) (stating that Florida's Canon 7(C)(1) applies to anybody, not just those who could appear in the court).

92 See $i d$. (explaining that the prohibition of monetary solicitations by a judge applies to everyone). See also id. at 1685 (Alito, J., dissenting) (advising that the prohibition on judicial candidates applies even if there is no chance the person will ever have any stake in a case in the court).
} 
potential for corruption and the appearance of impropriety are palpably higher in the judicial context than in the non-judicial context. ${ }^{93}$

The Court's critical-yet implicit-distinction between judicial and non-judicial elections presents in at least two critical ways. First, when it comes to a compelling governmental interest, comparing Citizens United and Williams-Yulee suggests that for non-judicial candidates the main concern pivots on the potential for a quid pro quo while for judicial elections the Court appears to worry about the appearance of impropriety and the public perception of judicial integrity. ${ }^{94}$ Second, a similar distinction emerges in the Court's application of the narrowly-tailored requirement. The Court has consistently permitted non-judicial candidates to directly solicit funds, though not from a candidate's official governmental office. ${ }^{95}$ In Williams-Yulee and the judicial electoral context, by contrast, the Court permitted Florida's total ban of direct fundraising solicitations by judicial candidates.

More fundamentally, however, the Court felt compelled to characterize judicial and non-judicial candidates for elected public office differently and in ways that triggered different judicial scrutiny over campaign finance issues. ${ }^{96}$ In an effort to climb out from under its earlier decision in Citizens United, the majority in Williams-Yulee took great pains to argue that judicial and non-judicial candidates are expected to act and campaign differently. ${ }^{97}$ The Court's decisions simply assert that states have a broader interest in preserving the appearance of judicial integrity than in preserving a similar appearance for those seeking legislative and executive offices. ${ }^{98}$

\section{PRIOR EMPIRICAL SCHOLARSHIP}

This study builds on and extends prior scholarship by Professors Kang and Shepherd which used an earlier (1995-98) state supreme court

\footnotetext{
93 See Case Comment, Williams-Yulee and the Anomaly of Campaign Finance Law, 126 YALE L.J. 1577, 1585 (2017) ("[s]tates have a broader interest in preserving the appearance of judicial integrity than in preventing the appearance of legislative and executive corruption"). 94 Compare Citizens United v. Fed. Election Comm'n, 130 S. Ct. 876, 908 (2010) (explaining that the goal of contribution limits is preventing quid pro quo corruption), with Williams-Yulee, 135 S. Ct. at 1673 (stating that there is a compelling interest in preserving judicial integrity). 95 See, e.g., HOUSE ETHICS MANUAL, supra note 89, at 132 (discussing the inability of politicians to solicit funds from governmental offices).

96 See Williams-Yulee, 135 S. Ct. at 1683 (Kennedy, J., dissenting) (" [s]ince judges should be accorded special respect and dignity, their election can be subject to certain content-based rules that would be unacceptable in other elections").

97 See id. at 1667 (discussing how the state's interest is different in judicial campaigns as opposed to legislative and executive campaigns).

${ }_{98}$ See id. (stating that because the roles of judges and politicians differ, legal rules regulating their respective campaigns should also differ).
} 
data set. ${ }^{99}$ Their earlier work found strong relations between the probability of an elected state supreme court justice's pro-business vote and the amount (and proportion) of campaign contributions that these justices received from pro-business interests. 100

Kang and Shepherd's findings in the business litigation context generally comport with analogous empirical work focusing on other litigation sectors. Professor Shepherd has also found that interest group judicial campaign contributions increase "the probability that judges will vote for the litigants favored by those interest groups." 101 In addition, an array of smaller-scale studies of individual states note relations between lawyers' campaign contributions and case outcomes when those lawyers (or the lawyers' interests) appear in court. ${ }^{102}$

Professor Shepherd's more recent empirical work focusing on the potential influence wielded by pro-business interests through judicial campaign contributions to state supreme court justices reinforces important-and uncomfortable-questions. ${ }^{103}$ Examining businessrelated cases decided by state supreme courts from 2010-12, Professor Shepherd's 2013 report, "Justice At Risk," similar to her prior work, finds "a significant relationship between business group contributions to state supreme court justices and the voting of those justices in cases involving business matters."104 Fueled by her empirical findings, Shepherd's normative perspective on the issue is clear when she characterizes campaign contributions' role in judicial elections as "destructive." 105

\footnotetext{
99 See Kang \& Shepherd, supra note 17, at 72 (analyzing new data that builds on data collected from 1995-1998).

100 See id. at 73 (finding that as judicial campaign contributions from big businesses increased, so too did the likelihood that judges will find for business litigants).

101 Joanna M. Shepherd, Money, Politics, and Impartial Justice, 58 DuKE L.J. 623, 669-72 \& tbls. 7 \& 8 (2009).

102 See, e.g., Stephen J. Ware, Money, Politics and Judicial Decisions: A Case Study of Arbitration Law in Alabama, 15 J.L. \& POL. 645, 661 (1999) (noting the influence of plaintiff and defense lawyers' contributions and favorable arbitration rulings by the Alabama Supreme Court); Eric N. Waltenburg \& Charles S. Lopeman, Tort Decisions and Campaign Dollars, 28 SE. POL. REV. 241, 24 (2000) (explaining the influence of plaintiff and defense lawyers' contributions and favorable torts cases in Ohio, Alabama, and Kentucky); Madhavi McCall, The Politics of Judicial Elections: The Influence of Campaign Contributions on the Voting Patterns of Texas Supreme Court Justices, 1994-1997, 31 POL. \& POL'Y 314, 315, 330 (2003) (finding that businessrelated judicial campaign contributions influenced case outcomes in the Texas Supreme Court).

103 See JOANNA SHEPHERD, JUSTICE AT RISK: AN EMPIRICAL ANALYSIS OF CAMPAIGN CONTRIBUTIONS AND JUDICIAL DECISIONS 1 (AM. CONST. SOC'Y. FOR L. \& POL'Y, June 2013), https://www.acslaw.org/ACS\%20Justice\%20at\%20Risk\%20(FINAL)\%206_10_13.pdf [http://perma.cc/ZX72-V5CT] (confirming a strong relationship between campaign contributions from businesses and state supreme court justice voting).

104 Id.

105 Id. at 2 .
} 
While Shepherd's recent brief report represents another important contribution to the literature, her analyses also open an array of additional research questions. This Article examines one of the research questions prompted by Shepherd's report.

Shepherd's 2013 report contributes to, and builds on, a nascent through growing-empirical literature that endeavors to assess and model judicial outcomes. ${ }^{106}$ As I discuss more fully below, core findings from Shepherd's 2013 study stood up well to replication efforts as well as most of her alternative model specifications. Setting aside one's priors about how to best reconcile constitutionally-protected core political speech, judicial campaign contributions, and the various selection mechanisms states employ for judges and justices, Shepherd's (and that of others) broad critique advanced against business interests' participation in judicial elections - even if empirically accurate-may either go too far or, paradoxically, not far enough. And only after deeper empirical exploration do the more abstract principles fall out of comparatively easy focus and nettlesome granularity and complicating wrinkles emerge.

Moreover, despite its contributions, a few factors, notably the potential for measurement error, limit the strength of Shepherd's 2013 findings. The data set (described more fully below) includes state supreme court decisions reached between 2010-12 and in states where state supreme court justices were elected in some manner (i.e., retention, partisan, or non-partisan elections). ${ }^{107}$ The data set leverages the justices' political party affiliation as a proxy (albeit imperfect) for judicial ideology. As Professor Kritzer observes, however, those state supreme court justices that confronted partisan elections before 2010 include those from southern states where "at least some of these justices were business-oriented Democrats."108 As such, the specter of measurement error lurks.

Any data set limitations notwithstanding, because my study extends Shepherd's 2013 report and data set, it is particularly important to note how my study differs. From the perspective of research design, Shepherd's focus on business cases (specifically business cases that reached state supreme courts between 2010 and 2012 which involved a business and a non-business litigant) makes good and obvious sense. After all, efforts to distill judicial outcomes require careful strategies to "keep all else constant," or at least as much as possible. Despite important variation within "business litigation," a focus on business litigation helps

\footnotetext{
106 See, e.g., sources cited supra note 102 (providing various legal scholarship regarding state judicial elections).

107 See infra Part IV (describing the data and variables used to extend prior work on judicial campaign funding).

108 Kritzer, supra note 5, at 366.
} 
rein in the sometimes tremendously complicating variation that exists across various cases, types, and litigating parties. Filtering the data set further to include only cases involving a business and a non-business litigant facilitates efforts to distill each individual justice's vote as either pro- or anti-business. The distillation of judicial votes to either a probusiness or anti-business characterization is particularly helpful for broader generalizations of the tort reform context that are frequently dominated by pro-business (or Chamber of Commerce) and anti-business (frequently union) interests.

Indeed, Shepherd's careful attention to research design only enhances a reader's confidence in her results. Building on their observation that "[a]lthough any interest group might exert influence over the judiciary, business groups may be unique in their ability to do so,"109 Professors Kang and Shepherd's existing work focuses on pro-business contributions' potential influence. According to Kang and Shepherd, business contributors' "substantial resources," more focused political and legal agenda, and greater "stake" in the outcome of judicial elections is what distinguishes them from non-business contributors. ${ }^{110}$

While Shepherd's data set is certainly well-suited to (and, indeed, designed for) her focus on pro-business interests' potential influence on judicial outcomes through campaign contributions, the data set also permits-even invites-further related exploration in two important ways. First, the data set includes information on each justice's campaign contributions from business interests as well as the total amount of each justice's campaign contributions. As such, simple data manipulations generated information on each justice's non-business campaign contributions. While each justice's non-business campaign contributions certainly warrant exploration, the nature of the non-business campaign contributions precludes strong generalizations. The interpretative limitations and ambiguity flow from the composition of the non-business contributions. Sources of non-business judicial campaign contributions range from a judicial candidate's own personal contributions to those from, for example, labor unions. While limiting my characterization of this sub-pool of campaign contributions as merely non-business may reflect over-caution, the varied and wide-ranging sources of funds that

\footnotetext{
109 Kang \& Shepherd, supra note 17, at 85.

110 See Kang \& Shepherd, supra note 17, at 85 (explaining that business groups may be unique in their ability to exert power over the judiciary due to their substantial resources and the great deal they have at stake in their support of judicial candidates).
} 
compose non-business contributions preclude a stronger characterization. ${ }^{111}$

Second, while the non-business sub-pool of campaign contributions may be inherently ambiguous, the data set also identifies and codes those non-business contributions from labor unions and democratic political party committees. ${ }^{112}$ Contributions from these two sources are far less ambiguous and are more plausibly characterized as anti-business. After all, labor unions enjoy a robust history opposing management and Shepherd's paper exploits a judge's political party as an ideological control variable signaling a judge's posture to business interests. ${ }^{113}$ Separate analyses focusing on the sub-pool of anti-business campaign contributions not only permits a stronger characterization of the nature of such contributions, but they also serve as a robustness check on the more general non-business findings.

In addition to expanding Shepherd's work by exploring alternative dependent variables, my models depart in a few (albeit minor) technical ways from Shepherd's models. First, while Shepherd's main model construes business contributions in terms of their raw total as well as in terms of a percentage of total judicial campaign contributions, my analyses focus only on business (and non-business and anti-business) contributions as a percentage of total campaign contributions. Second, because the political science and empirical legal literatures on judicial decision-making typically include a measure of how much time remains on a judge's (or a governor's) elected term when a decision was reached, my models include a dummy variable signaling whenever a justice voted on a case with two or fewer years remaining on her elected term to the bench.

Third, Shepherd's models include dummy variables identifying democrat and republican justices. The reference group in Shepherd's report, for interpretative purposes, involves those justices whose political affiliation was either missing or coded for something other than democrat

111 See SHEPHERD, supra note 103, at 22 n.64 (noting that the non-business contributions include those from "interests often opposed to business," and that Shepherd felt that reflexively construing all non-business contributions as anti-business, invited measurement error).

112 See id. at 1 (presenting general information on the manner data was gathered that included gathering data on all contributions made, which would include labor union contributions and contributions from democratic political party committees).

113 See, e.g., Melvyn Dubofsky, AMERICAN LABOR SinCE THE New DEAL 59-60, 62 (Melvyn Dubofsky, 1971) (showing one perspective on labor unions' uneasy relation with management over time). See also Thomas B. Edsall, Republicans Sure Love to Hate Unions, N.Y. TIMES (Nov. 18, 2014), https:/ / www.nytimes.com/2014/11/19/opinion/republicans-surelove-to-hate-unions.html?mcubz=0 [http://perma.cc/U2HV-GT65] (providing an essay exploring labor unions' traditional political support for democrats). 
or republican. As I describe in greater detail below, my models include only one dummy variable identifying either democrat or republican justices. ${ }^{114}$ (Alternative specifications include dummy variables for "democrat" and "republican," respectively.) In this way, my model specifications consciously "stack-the-deck" against the potential salience of a justice's political affiliation. Thus, where a justice's political affiliation achieves statistical significance, my coding decisions should increase readers' confidence in the finding. As I describe below, however, my coding decisions also contributed to some political salience results that depart slightly from Shepherd's earlier results.

\section{Data, Methodology, AND Research Design}

To test the possible influence of campaign contributions from pro-, non-, and anti-business sources on state supreme court justices' votes in cases where one of the litigating parties is a business interest, I use a data set constructed by Professor Shepherd that itself is the product of four discrete data sets, each briefly described below. ${ }^{115}$ First, a team of independent researchers from Emory University School of Law collected and coded state supreme court decisions $(\mathrm{N}=30,355)$ between 2010 and 2012 and across all fifty states. ${ }^{116}$ A sub-set of this data set, 21,105 entries $(69.5 \%)$, involved cases where the identified business interest was on one-and only one-side of the litigation. This filtering was necessary for research design purposes as outcomes in these cases facilitate an assessment of the degree to which, if any, business campaign contributions may have informed justices' votes in business-related cases. For each case, the researchers coded whether each participating justice, sitting as a member of a multi-judge appellate panel, cast either a pro- or anti-business vote in a case.

A second data set includes information on the more than 175,000 contribution records that detail every reported contribution to every sitting state supreme court justice between 2010-12 in each elected state supreme court justice's most recent election. These data were collected by the National Institute on Money in State Politics ("Institute"), a nonpartisan, nonprofit charitable organization that focuses on data gathering on campaign finance activity in all fifty states. The Institute obtains the campaign finance data in either electronic or paper form from state disclosure agencies. The Institute assigned each donor an economic

\footnotetext{
114 See infra Part IV.

115 See SHEPHERD, supra note 103, at 10 (outlining the four discrete data sets that were compiled by Professor Shepherd).

116 See id. at 1 (describing the independent team's data gathering of court decisions from all fifty states between 2010 and 2012).
} 
interest code determined by information included in the disclosure reports as well as deeper independent research into the donor's economic background and interests. From the Institute data, campaign contribution data for all judges in the sample data who were candidates in both partisan and nonpartisan state supreme court races were computed.

A third data set includes political party affiliations (if any) for each of the 439 state supreme court justices and a fourth contains state-specific information on how each state selects and retains its supreme court justices. Once merged, the final data set includes justice-level information on 439 state supreme court justices who participated in 2,345 concluded business-related cases, every justice's vote in each case, along with an array of contextual and background information (on the justice, campaign contributions, case, court, and state) that might help explain a justice's vote.

\section{A. Description of Key Variables}

The following key variables explore the relation between justices' votes favoring a business litigant and judicial campaign contributions from business and non-business interests. To better isolate the independent influence of campaign contributions, the models include an array of standard control variables.

\section{Dependent Variables}

The dependent variable is a dummy variable signaling when a justice voted in favor of the business litigant. A judicial vote is coded as probusiness if the end result favored or advantaged the business litigant, regardless of whether the actual judge vote took the form of a reversal, affirmance, or damage award alteration. In model specifications that explore the influence of non- and anti-business campaign contributions, the dependent variable signals when a justice voted in favor on the nonbusiness litigant. 117

\section{Key Independent Variables of Interest}

The key independent variables of interest include judicial campaign contributions from pro-, non-, and anti-business interests. While an exact measure of a pro-business interest eludes, I followed Shepherd's coding convention and defined pro-business interests' campaign contributions to include those from agriculture, communications, construction, defense,

117 See id. at 12 (presenting an explanation for what the dependent variable in the analysis examining the biasing effects of judicial campaign contributions on judicial decisions). 
energy, finance and real estate, and general business sources. ${ }^{118}$ Nonbusiness contributions were computed to include all financial contributions that came from sources other than those identified as a probusiness source. ${ }^{119}$ Finally, anti-business contributions, a sub-pool of the non-business contributions, include only those contributions from either labor unions or democratic party political committees. ${ }^{120}$

Insofar as the raw total amount of judicial campaign contributions from pro-, non-, and anti-business sources varied across judges, along with variation in a justice's total campaign contributions, all pro-, non-, and anti-business judicial campaign contributions are expressed as a percentage of each justice's total campaign contributions. As Professor Shepherd notes, "[ $t$ ]his is likely a more accurate measure of business influence [on a particular justice] because the impact of a contribution likely depends on its importance relative to other contributions." 121

While the pro-, non-, and anti-business contributions are expressed as a percentage of each justice's total amount of campaign contributions, to get a better sense as to their relative contribution, the magnitude of a justice's campaign contributions also warrants attention. Accordingly, all of the model specifications include a variable reflecting the raw total of each justice's campaign contributions. Finally, all judicial campaign contributions are expressed as natural logs.

\section{Control Variables}

All model specifications include various control variables at the case, justice, and state levels. In addition, because the outcome of individual cases within a state or by the same justice might not include the necessary independence from one another, case outcomes are clustered at the stateand individual-justice levels.

118 See id. at 10 (explaining that for robustness purposes, and to tether this work with prior, related work, alternative supplemental specifications considered a narrower definition of "pro-business interests" that included only business-related contributions from finance and real estate, "general" business, and health industry sources). See, e.g., Kang \& Shepherd, supra note 48, at 1271 (showing that prior literature defines a narrower definition of business interests as those aligning with "conservative" interests and agenda). Id. at 1270 n.129 (discussing that unpublished results from these alternative specifications are generally consistent with a broader definition of pro-business contributions).

119 See SHEPHERD, supra note 103, at 12 (noting that non-business contributions equaled total contributions minus pro-business contributions).

120 See infra note 121 and accompanying text (describing the composition of anti-business contributions).

121 See SHEPHERD, supra note 103, at 10-12. Nonetheless, as a robustness check, I re-ran in supplemental analyses (unreported) models whose results are presented in tbls.1-3. See also infra Tables 1-3 (substituting raw totals for percentages as a measure of business contributions to judicial campaigns did not materially affect the substantive results). 
While cases in this study are limited to business litigation (signaled by the presence of a business litigant), important variation can exist within business cases. A case's underlying legal merits, to some degree, inform a justice's vote and the legal strength of business cases can vary. In this context, it is possible that some of the business cases heard by state supreme courts were either so strong or weak on the legal merits that justices voted for (or against) the business interest independent of any campaign contributions received from pro-, non-, or anti-business interests or the justices' ideological preferences (signaled by a judge's political party affiliation or, if none existed, by imputing to a judge an appointing governor's political party). ${ }^{122}$

How to measure a case's underlying legal strength, however, remains contested. By definition, every case in this study persisted through a trial and, in most states, some level of intermediate appellate review before it reached a state supreme court for resolution. Presumably, and consistent with case selection theory, cases whose underlying legal merits that strongly tilt in either direction (either pro-plaintiff or pro-defendant) would likely have succumbed to settlement pressures rather than persisting through state supreme court review. While Priest-Klein theory implies that only cases where some degree of objective uncertainty exists about a case's outcome would persist to a state supreme court for disposition (and, if so, this would result in win rates that approximate fifty percent), empirical work makes clear how important variation exists in terms of observed win rates across case types. ${ }^{123}$ What is equally clear, however, is that some of the assumptions underneath the Priest-Klein prediction, including asymmetric information, similar stakes invested by both parties to a lawsuit, and accurate ex ante assessments about a case's underlying legal merits, do not hold with the precision that theory might imply. ${ }^{124}$

In an effort to control the underlying legal strength of the cases (however imperfectly), I incorporate the clever case strength variable crafted by Professor Shepherd. In constructing a measure of case strength, Professor Shepherd initially estimated a model without a case strength variable to assess the most likely number of pro-business votes for the

\footnotetext{
122 See id. at 14 (noting that despite business contributions, judges can also vote owing to their political beliefs). See also Gregory C. Sisk \& Michael Heise, Judges and Ideology: Public and Academic Debates About Statistical Measures, 99 Nw. UNIV. L. REV. 743, 745 (2005) (discussing the robustness of political party as a proxy for a judge's ideological preferences). 123 See George Priest \& Benjamin Klein, The Selection of Disputes For Litigation, 13 J. LEGAL STUD. 1 (1984). See also Yoon-Ho Alex Lee, \& Daniel Klerman, The Priest-Klein Hypothesis: Proofs and Generality, 48 INT'L REV. L. \& ECON. 59, 65 (2016) (highlighting the Priest-Klein's hypothesis of case variations and outcomes).

124 See Lee \& Klerman, supra note 123 , at 70.
} 
state justices hearing the case. The estimated number of pro-business votes exploits information on each justice's political party affiliation. Backing-out the actual number of pro-business judicial votes observed in a case from the number of estimated pro-business judicial votes provides a sense of the underlying strength of the case's legal merits.

To illustrate, consider a model estimation predicting that five of the seven state justices would vote in favor of the business interest. If in the actual case six of the seven justices voted in favor of the business interest, the value of the case strength variable in this case would be positive suggesting that the underlying legal strength of the case is stronger than predicted. If, in contrast, only two of the seven justices voted in favor of the business interest, the case strength variable would be negative, indicating a comparatively weaker case on the legal merits. By computing the difference (if any) between the predicted (modeled) number of probusiness votes and the observed number of pro-business votes in each case generates a case strength variable, which provides some insight into a case's underlying legal strength that will influence judicial outcomes intendent of judicial campaign contributions from business interests. The inclusion of the case strength variable as a control is designed to help isolate the potential unique influence of campaign contributions from pro-, non-, and anti-business interests on justices' decisions in business cases.

To further address possible selection effect influences, a final caselevel control variable signals when the petitioner was the business litigant (in the pro-business model) and the non-business litigant (for the non- and anti-business models). At the individual justice-level, Professor Shepherd's 2013 analysis includes dummy variables for both republican and democratic justices as a (imperfect) proxy for judicial ideology. ${ }^{125}$ Consequently, for interpretative purposes, the appropriate reference for each political party dummy variable is the comparatively smallest group of justices (almost twelve percent) who are either a member of a political party other than republican or democrat or, in contrast, are those for whom information on their political affiliation is missing.

My analyses, by contrast, reflect a slightly different coding decision on how best to treat judges whose political affiliation is either unknown, missing, or something other than republican or democrat. By including in my models only one dummy variable for a justice's political affiliation (republican or democrat), my model facilitates a more intuitive reference point (e.g., republican justices as compared to all other justices who are not republican). Moreover, such a coding strategy is also structurally more

125 See SHEPHERD, supra note 103, at 12 (describing Shepherd's use of political party affiliation to signal judicial ideology). 
conservative insofar as it treats all unknowns as something other than what the coefficient captures. ${ }^{126}$ Insofar as my coding convention is structured to mute the attribute I assess, where a justice's political affiliation variable achieves statistical significance, confidence about its actual influence should increase.

Finally, Shepherd's models omit any information on how much time remains in a justice's elected term when she voted in a case.127 Political science literature on judicial outcomes emphasizes how judicial conduct may be influenced as justices approach electoral events, particularly in the criminal law domain. ${ }^{128}$ As a result, my model includes a dummy variable that signals when a judge voted in a case within two years of the end of a judicial term.

The models also include an array of state-level controls, beginning with variables signaling whether a state's method of judicial elections were partisan or non-partisan contests. ${ }^{129}$ As well, in states where the existing legal climate is business-friendly, one might reasonably expect more judicial votes favoring business interests regardless of a judge's business-related judicial campaign contributions. To better isolate the potential influence of campaign contributions from a state's overall business legal climate, the models include a tort liability index, constructed by the Pacific Research Institute. ${ }^{130}$ Finally, as judicial votes in business-related cases may also reflect public preferences or ideological trends, the models include a traditional and well-known measure of a

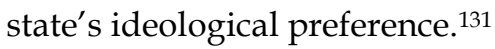

\footnotetext{
126 Cf. Follow the Money; Shepherd (2013) data sets.

127 See SHEPHERD, supra note 103, at 17-20 (noting that Shepherd's models do not take into account how much time is left on a judge's elected term).

128 See, e.g., Kenneth Bresler, Seeking Justice, Seeking Election, and Seeking the Death Penalty: The Ethics of Prosecutorial Candidates' Campaigning on Capital Convictions, 7 GEO. J. LEGAL ETHICS 941, 941-43 (1994) (detailing pressures generated by prosecutors' electioneering). See also Ronald J. Tabak, Commentary, Politics and the Death Penalty: Can Rational Discourse and Due Process Survive the Perceived Political Pressure?, 21 FORDHAM URB. L.J. 280, 280-81 (1994) (describing the perceived political pressures associated with death penalty decisions); Michael Heise, The Death of Death Row Clemency and the Evolving Politics of Unequal Grace, 66 ALA. L. REV. 949, 980-81 (2015) (assessing the influence of reelection cycles on clemency grants for death row inmates).

129 See SHEPHERD, supra note 103, at 11.

130 See Lawrence J. McQuillan \& Hovannes Abramyan, U.S. Tort Liability Index, 2010 Report, PAC. RES. INST., http://www.civiljusticenj.org/wp-content/uploads/2014/08/2010_Tort_ Liability_Index.pdf [https://perma.cc/V225-8FLD] (noting that the index uses data available as of Oct. 1, 2009).

131 See William D. Berry et al., Measuring Citizen and Government Ideology in American States, 1960-93, 42 AM. J. POL. SCI. 327, 327 (1998) (showing that the index uses updated data through 2008).
} 


\section{B. Methodology and Research Design}

The cases in this study are limited in two important ways. First, the data include civil litigation where a business interest was on one, and only one, side of the litigation. ${ }^{132}$ Limiting the data set in this way facilitates characterizing each justice's vote as either pro-business or not probusiness. Second, the analyses include only those states where state supreme court justices are elected in some manner (i.e., retention, partisan, or non-partisan elections). While not all state supreme court justices confront some form of election, as Figure 1 (below) makes clear, judicial campaign contributions do not exist where judicial elections do not exist. While collapsing the three major forms of judicial elections might invite criticism, Figure 1 illustrates that even judicial retention elections attract some level of campaign contributions (though far less than non-partisan and partisan judicial elections). Potential criticism aside, including all forms of judicial elections is necessary to tether this study to prior empirical work in this field. ${ }^{133}$

\section{RESULTS AND DISCUSSION}

Empirical results - both descriptive and more granular regression models - help explain various influences on state supreme court justices' votes in business cases. ${ }^{134}$

\section{A. Descriptive Results}

How states structure judicial elections influences business contributions to judicial campaigns. ${ }^{135}$ Figure 1 illustrates how business contributions to judicial campaigns distribute across the four major judicial selection mechanisms. As one would expect, in states where supreme court justices are appointed rather than elected, justices received no business-related contributions. Where elections select state supreme court justices, by contrast, business interests participate in those campaigns partly through financial contributions. The percentage of business-related contributions varies among the three major judicial election forms - retention, nonpartisan, and partisan. Again, consistent with common sense, Figure 1 illustrates that the percentage of business-

\footnotetext{
132 See SHEPHERD, supra note 103, at 11 (describing Shepherd's research design).

133 See $i d$. at 4 (establishing that the study looked at several types of election processes, which allowed for a more complete and extensive study).

134 See id. at 12 (explaining that granular regression models are useful in studies of influence on judges).

135 See id. at 13 (discussing how state constructions of judicial retention can influence how judges receive business contribution).
} 
related judicial campaign contributions were at their highest in partisan judicial elections and lowest in retention elections.

Figure 1: Distribution of Pro-Business Contributions (\%) Across Various Methods of State Supreme Court Justice Selection

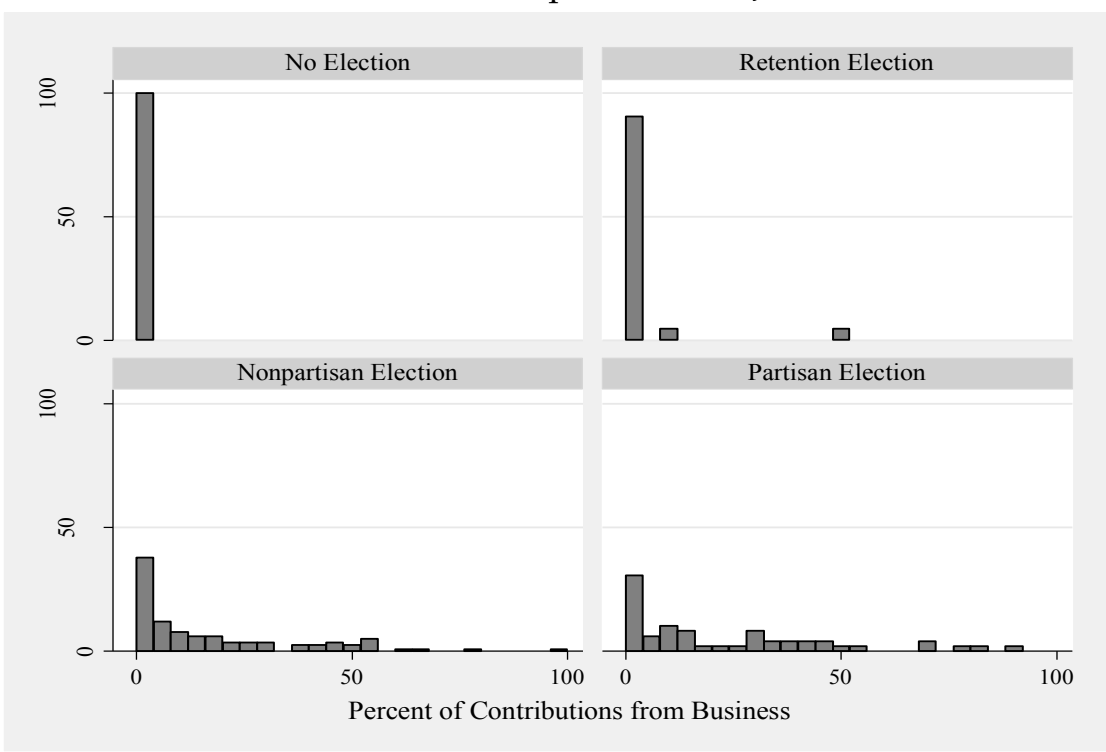

SOURCES: Follow the Money; Shepherd (2013) data sets.

One important way this Article expands on Shepherd's 2013 analysis is by including judicial campaign contributions from non-business interests. Consequently, it is important to view business and non-business contributions in relation to one another. Figure 2 presents kernel density estimates of the distributions of (logged) business and non-business campaign contributions as a percentage of total campaign contributions and the line patterns inform. Specifically, the overall visual impression is one of an " $X$," with the business and non-business lines intersecting just past the fifty percent point. That is, the business and non-business lines essentially reflect one another. Of course, given the somewhat reciprocal nature of the coding protocols for the business and non-business contribution variables, the visual pattern emerging in Figure 2 does not surprise. While Figure 2 does reveal some degree of overlap (that is, some justices received campaign contributions from both business and nonbusiness sources), the overall impression is one of separation. That is, most judicial candidates received the bulk of their campaign contributions from either business or non-business interests. 
Figure 2: Kernel density estimates, pro-business and non-business contributions

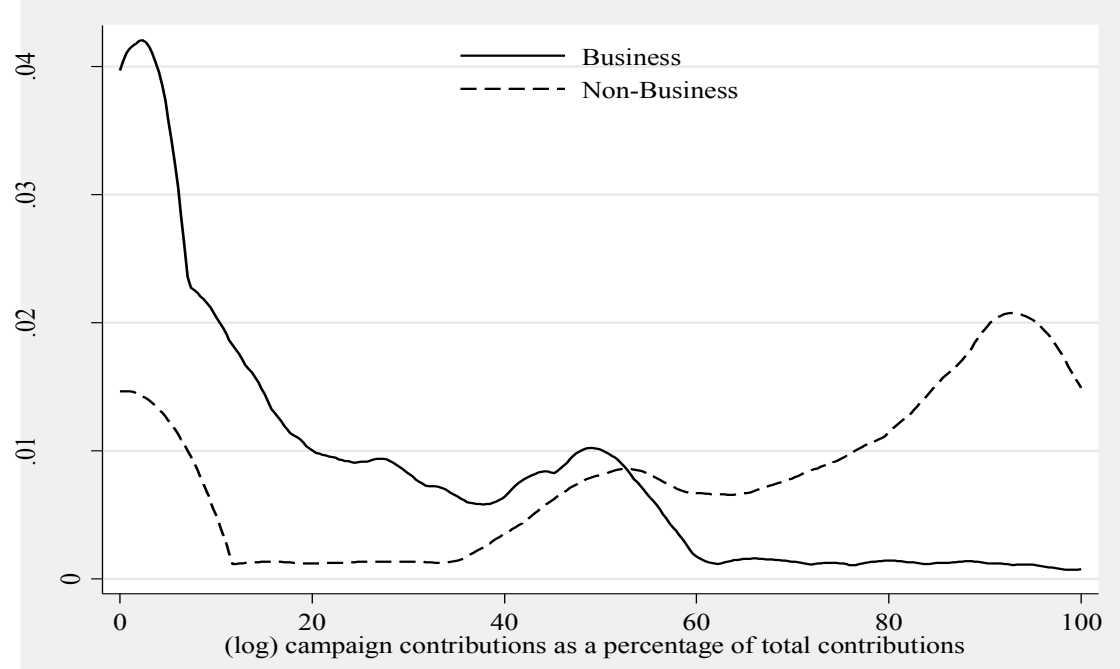

SOURCES: Follow the Money; Shepherd (2013) data sets.

\section{B. Regression Results}

While the descriptive results comport with intuitive notions about the relation between judicial selection methods and business campaign contributions in judicial elections, as well as between business and nonbusiness judicial campaign contribution trends, more nuanced regression analyses are necessary to isolate and identify possible relations between business (and non-business) contributions and judicial votes in business cases.

\section{Pro-Business Judicial Campaign Contributions}

Table 1 presents results from the mixed effects models on business campaign contributions' influence on judge votes in business cases. As it relates to the key variable of interest-campaign contributions from business interests (expressed as a percentage of a justice's total campaign receipts) - results in Table 1 make clear that as the percentage of a justice's campaign contributions from pro-business interests increased, so too did the likelihood of the justice voting in a manner that favors the business litigant. Interestingly, at the same time, an increase in total campaign contributions corresponds with a reduction in the likelihood of a justice casting a pro-business vote. Among the various types of judicial election mechanisms, partisan elections were more likely to generate justices who 
cast pro-business votes. Justices' ideology (expressed through political party affiliation) also achieves statistical significance and it does so in the expected directions. That is, while republican justices were more favorable to business litigants, democratic justices were systematically less favorable (Table 1, columns A and B, respectively). A state's tort climate, another important control variable, also achieves statistical significance in the expected direction; an increase in a state's liability index corresponds with a decreased likelihood of a pro-business judicial outcome. Finally, case strength also proved important. As a business case's underlying legal strength increased, so too did the likelihood of a justice vote in favor of the business interest.

Notably, when the business interest was the petitioner, the likelihood of a pro-business outcome decreased. Interestingly, a similar finding emerges in both non-business models as well. That the petitioner status variable's association with decreasing the probability of a favorable judge vote cuts across the business/non-business divide implies that what it signals may have little to do with the business (or non-business) context. While these data and models do not address this particular question, it remains possible that these findings reflect a "pro-affirmance" bias at the state supreme court level. Setting aside selection effects' important influences on appellate reversal rates as well as variations across case types, prior work on various civil appellate contexts (including state and federal) implies an overall impression of the comparative difficulty that petitioners confront when seeking to overturn a lower court decision. ${ }^{136}$ Thus, the finding in Table 1 suggesting that business petitioners reduce the probability of a judge voting in favor of the business litigant needs to be understood within an appellate context that, on balance, displays a general tilt toward respondents independent of the business litigation context.

\footnotetext{
136 See Theodore Eisenberg \& Michael Heise, Plaintiphobia in State Courts Redux? An Empirical Study of State Court Trials on Appeal, 12 J. EMPIRICAL LEGAL STUD. 100, 110 (2015), tbl.1 (summarizing state and federal civil appeals reversal rates).
} 
TABLE 1: MiXed EFFECTS MODEL OF PRO-BUSINESS JUdiCIAL CAMPAIGN CONTRIBUTIONS' INFLUENCE ON JUDICIAL VOTING IN BUSINESS CASES (2010-2012)

\begin{tabular}{|c|c|c|c|c|}
\hline Judge vote favoring business litigant: & (A) & (s.e.) & (B) & (s.e.) \\
\hline Pro-Business campaign contrib. (\% of ttl.) & $0.210 * *$ & $(0.07)$ & $0.211 * *$ & $(0.07)$ \\
\hline Total campaign contrib. $(\$ 10 \mathrm{~K})$ & -0.111 * & $(0.05)$ & -0.124 ** & $(0.05)$ \\
\hline Non-partisan judicial election & -0.150 & $(0.35)$ & -0.249 & $(0.34)$ \\
\hline Partisan election & 0.775 * & $(0.38)$ & 0.915 * & $(0.38)$ \\
\hline Justice $\mathrm{w} /$ in 2 years of term end & -0.044 & $(0.15)$ & -0.019 & $(0.15)$ \\
\hline Republican justice & $0.712 * *$ & $(0.19)$ & --- & -- \\
\hline Democrat justice & --- & --- & -0.846 ** & $(0.20)$ \\
\hline State tort climate & $-0.761 * *$ & $(0.23)$ & $-0.835 * *$ & $(0.23)$ \\
\hline State citizen ideology & -0.002 & $(0.01)$ & -0.006 & $(0.01)$ \\
\hline State elite ideology & -0.010 & $(0.01)$ & -0.012 & $(0.01)$ \\
\hline Business litigant was petitioner & $-0.463 * *$ & $(0.10)$ & $-0.461 * *$ & $(0.10)$ \\
\hline Case strength & $0.072 * *$ & $(0.00)$ & $0.072 * *$ & $(0.00)$ \\
\hline Constant & 0.317 & $(0.58)$ & 0.562 & $(0.57)$ \\
\hline$(N)$ & 7,112 & & 7,112 & \\
\hline
\end{tabular}

NOTES: ${ }^{*} p<0.05 ;{ }^{* *} p<0.01$. Robust standard errors in parentheses. These models include all pro-business campaign contributions (logged) as a percentage of a justice's total amount of campaign contributions (logged). All model specifications include state- and justice-level clusters. Mixed effects models estimated using the "meqrlogit" command in Stata (v.14.1). Model A includes the republican justice dummy variable; model B includes the democrat justice dummy variable.

SOURCES: Follow the Money; Shepherd (2013) data sets. 
Although my model specifications depart slightly from Shepherd's, ${ }^{137}$ results in Table 1 largely track Shepherd's main findings presented in her 2013 report. ${ }^{138}$ Shepherd's analyses focus on the influence of pro-business campaign contributions and, having successfully largely replicated Shepherd's core results, this paper extends Shepherd's by turning to the possible influence of non- and anti-business campaign contributions on justices' votes that favored non-business litigants.

\section{Non-Business Judicial Campaign Contributions}

Table 2 reports results after essentially "flipping" Shepherd's basic model. That is, where Table 1 reports results from models assessing the relation between pro-business judicial campaign contributions and the probability that a justice voted in favor of the business litigant, Table 2, by contrast, assesses the possible influence of non-business judicial campaign contributions on the likelihood that a justice voted in favor of the nonbusiness litigant.

While a robust inference from Table 1 might induce an expectation for reciprocal findings in Table 2, results in Table 2 provide only partial support for such expectations. Specifically, as it relates to the particular variable of interest, Table 2 illustrates that non-business judicial campaign contributions correlate with an increased likelihood of a judicial judge votes is present for both pro- and non-business settings, the influence is comparatively stronger for the pro-business setting.

While analyses of pro- and non-business judicial campaign contributions' efficacy in terms of influencing favorable judicial outcomes uncovers a few subtle differences, the overall weight of the results conveys a stronger sense of convergence. For example, the relation between nonbusiness contributions and judge votes is just as pronounced for democratic and republican judges, though in the expected opposite directions. Moreover, the case strength variable achieves statistical significance (and in the expected direction). ${ }^{139}$ Finally, the influence of a non-business interest petitioner significantly decreases the likelihood of a non-business vote. As discussed previously, a similar finding emerges in the pro-business context and both may have more to do with a general "pro-affirmance" tilt in civil appellate litigation than with judicial campaign contributions.

\footnotetext{
137 See SHEPHERD, supra note 103 , at 17.

138 See id. (explaining Shepherd's main findings).

139 See infra Tables 2 \& 3 (describing the underlying legal strength of a pro-business case became "stronger," it reduced the probability of a judge vote favoring the non- [tbl.2] and anti-business [tbl.3] interest).
} 
TABle 2: MiXed EFFECTS MODEl of NON-Business JudiCiAl CAMPAigN CONTRIBUTIONS' INFLUENCE ON JUDICIAL VOTING IN BUSINESS CASES (2010-2012)

\begin{tabular}{|c|c|c|c|c|}
\hline Judge vote favoring non-business litigant: & (A) & (s.e.) & (B) & (s.e.) \\
\hline Non-Business campaign contrib. (\% of ttl.) & 0.088 * & $(0.04)$ & 0.090 * & $(0.04)$ \\
\hline Total campaign contrib. $(\$ 10 \mathrm{~K})$ & -0.078 & $(0.04)$ & -0.067 & $(0.04)$ \\
\hline Non-partisan judicial election & -0.144 & $(0.36)$ & -0.038 & $(0.35)$ \\
\hline Partisan election & -0.834 * & $(0.38)$ & $-0.986 * *$ & $(0.38)$ \\
\hline Justice w/in 2 years of term end & 0.080 & $(0.15)$ & 0.054 & $(0.15)$ \\
\hline Republican justice & $-0.793 * *$ & $(0.19)$ & --- & --- \\
\hline Democrat justice & --- & -- & $0.922 * *$ & $(0.20)$ \\
\hline State tort climate & $0.641 * *$ & $(0.24)$ & $0.721 * *$ & $(0.23)$ \\
\hline State citizen ideology & 0.006 & $(0.01)$ & -0.003 & $(0.01)$ \\
\hline State elite ideology & 0.011 & $(0.01)$ & 0.012 & $(0.01)$ \\
\hline Non-business litigant was petitioner & $-0.468 * *$ & $(0.10)$ & -0.466 ** & $(0.10)$ \\
\hline Case strength & $-0.072 * *$ & $(0.00)$ & $-0.072 * *$ & $(0.00)$ \\
\hline $\begin{array}{l}\text { Constant } \\
\text { (N) }\end{array}$ & $\begin{array}{l}-0.103 \\
7,112\end{array}$ & $(0.59)$ & $\begin{array}{l}-0.391 \\
7,112\end{array}$ & $(0.57)$ \\
\hline
\end{tabular}

NOTES: ${ }^{*} p<0.05 ;{ }^{* *} p<0.01$. Robust standard errors in parentheses. These models include all non-business campaign contributions (logged) as a percentage of a justice's total amount of campaign contributions (logged). All model specifications include state- and justice-level clusters. Mixed effects models estimated using the "meqrlogit" command in Stata (v.14.1). Non-business judicial campaign contributions include all contributions other than pro-business contributions. Model A includes the republican justice dummy variable; model B includes the democrat justice dummy variable.

SOURCES: Follow the Money; Shepherd (2013) data sets. 
3. Anti-Business Judicial Campaign Contributions

While judicial campaign contributions' varied sources permit the identification of sources plausibly construed as "pro-business," the construction of the non-business contributions do not, as Shepherd briefly notes, easily support a characterization of them as "anti-business." 140 Rather, for interpretative purposes, results in Table 2 can only be understood (at least conservatively and cautiously) as "non-business." A deeper understanding of whether judicial campaign contributions plausibly characterized as "anti-business" is possible only after constructing a new variable, which includes a sub-pool of non-business contributions limited to contributions from labor unions and democratic party campaign committees. This alternative specification also provides something of a robustness check on the stability of the prior findings.

As Table 3 illustrates, the main findings that emerge in Table 2 remain intact. All of the variables that achieve statistical significance in the nonbusiness model retain their significance in the anti-business model. Importantly, the presence of judicial campaign contributions from antibusiness sources systematically correlate with an increased probability of a judge voting in favor of the non-business litigant. And this finding emerges after controlling for the underlying legal strength of the case (as well as the independent influence of other control variables). Similar to earlier findings, the influence of judicial campaign contributions on judicial outcomes achieves statistical significance only in the partisan election context. Another factor that links Tables 1, 2, and 3 is the consistent salience of a party's status as a petitioner. Again, as previously discussed, it remains a distinct possibility that this variable is picking up a possible "affirmance bias" present in state supreme courts. Finally, if nothing else, that Table 3's results essentially track those in Table 2 conveys the overall findings' stickiness and robustness to alternative model specifications.

\footnotetext{
140 Cf. SHEPHERD, supra note 103, at 16 (construing judicial campaign contributions as either "pro-business" or "anti-business").
} 
TABLE 3: MiXed EFFECTS MODEL OF ANTI-Business JUdiCIAL

CAMPAIGN CONTRIBUTIONS' INFLUENCE ON JUDICIAL VOTING IN BUSINESS CASES (2010-2012)

\begin{tabular}{|c|c|c|c|c|}
\hline Judge vote favoring non-business litigant: & (A) & (s.e.) & (B) & (s.e.) \\
\hline Anti-Business campaign contrib. (\% of ttl.) & 0.129 * & $(0.06)$ & 0.142 * & $(0.06)$ \\
\hline Total campaign contrib. $(\$ 10 \mathrm{~K})$ & -0.024 & $(0.03)$ & -0.014 & $(0.03)$ \\
\hline Non-partisan judicial election & 0.006 & $(0.35)$ & 0.105 & $(0.34)$ \\
\hline Partisan election & -0.925 * & $(0.39)$ & $-1.080 * *$ & $(0.39)$ \\
\hline Justice $\mathrm{w}$ / in 2 years of term end & 0.074 & $(0.15)$ & 0.048 & (0.15) \\
\hline Republican justice & $-0.729 * *$ & $(0.20)$ & --- & --- \\
\hline Democrat justice & --- & --- & $0.878 * *$ & $(0.20)$ \\
\hline State tort climate & $0.775^{* *}$ & $(0.23)$ & $0.854^{* *}$ & $(0.23)$ \\
\hline State citizen ideology & 0.004 & $(0.01)$ & -0.005 & $(0.01)$ \\
\hline State elite ideology & 0.005 & $(0.01)$ & 0.006 & $(0.01)$ \\
\hline Non-business litigant was petitioner & $-0.470 * *$ & $(0.10)$ & $-0.470 * *$ & $(0.10)$ \\
\hline Case strength & $-0.072 * *$ & $(0.00)$ & $-0.072 * *$ & $(0.00)$ \\
\hline Constant & 0.472 & $(0.65)$ & 0.288 & $(0.63)$ \\
\hline$(N)$ & 7,112 & & 7,112 & \\
\hline
\end{tabular}

NOTES: ${ }^{*} p<0.05 ;{ }^{* *} p<0.01$. Robust standard errors in parentheses. These models include anti-business campaign contributions (logged) as a percentage of a justice's total amount of campaign contributions (logged). All model specifications include state- and justice-level clusters. Mixed effects models estimated using the "meqrlogit" command in Stata (v.14.1). Anti-business judicial campaign contributions include funds from either labor unions or democratic party committees (or both). Model A includes the republican justice dummy variable; model B includes the democrat justice dummy variable.

SOURCES: Follow the Money; Shepherd (2013) data sets. 
C. Discussion

Results from Table 1, independently and in conjunction with prior empirical work, provide support for those worried about the potentially distorting influence of judicial campaign contributions from pro-business interests on judicial outcomes. ${ }^{141}$ Indeed, similar findings from her own related analyses prompted Professor Shepherd to characterize probusiness judicial campaign contributions' role as "destructive." 142 And Shepherd's normative conclusions are echoed by others. ${ }^{143}$

Equally important as the findings on the influence of pro-business judicial campaign contributions (Table 1) are findings of similar influences achieved by non- and anti-business contributions (Tables 2 and 3, respectively). Expanding and building upon Shepherd's earlier work reveals that Shepherd's analyses (and conclusions) speak to only one piece of a more complex judicial campaign contribution puzzle. The pieces provided by my additional analyses complicate Shepherd's normative implications as well as prevailing wisdom. Specifically, results from Tables 2 and 3 can certainly be understood to either exacerbate or reduce worries about business' potential undue influence. On the one hand, the new findings may only deepen fears about elected state supreme court justice decisions' vulnerability to campaign contributions. After all, the weight of the results from Table 1, 2, and 3 imply that the ability to influence judicial votes extends far beyond pro-business efforts.

On the other hand, results illustrating that non- and anti-business interests' campaign contributions influenced judicial outcomes similar to pro-business contributions may also, paradoxically, reduce overall worries about the relation between judicial contributions and outcomes. That is to say, evidence that any interest group willing and able to invest in judicial campaigns can influence judicial outcomes might dilute fears about the undue influence of any one particular group. While one may reasonably feel uneasy about the influence of judicial campaign contributions on judicial outcomes, perhaps some comfort flows from the realization that any such influence is not limited to one particular viewpoint (e.g., pro-business interests). Of course, it bears emphasis that evidence of positive relations between pro-, non-, and anti-business sources and favorable does not establish causation. Indeed, in this particular context, a critical question that endures due to research design and data limitations involves whether such evidence reflects selection or

\footnotetext{
141 See infra Table 1 (describing the mixed effects model of pro-business judicial campaign contributions' influence on judicial voting in business cases).

142 See SHEPHERD, supra note 103, at 2.

143 See, e.g., Charles G. Geyh, Why Judicial Elections Stink, 64 OHIO ST. L.J. 43, $46-47$ (2003) (explaining the finding that pro-business campaign contributions are destructive).
} 
inducement effects. That is, to take one example, the positive correlation between pro-business campaign contributions to judicial candidates may be a function of such contributions making it easier for pro-business candidates to win their judicial elections or, in contrast, inducing winning judges to reach pro-business outcomes. ${ }^{144}$

Important causal inference limitations notwithstanding, at the very least what my results accomplish at an empirical level is to help place Shepherd's critique of businesses' influence on state supreme courts into a broader interpretative context and expand on what we know about the influence of judicial campaign contributions and judicial outcomes. At a normative level, one implication from my results is that while Shepherd's characterization of judicial campaign contributions as "destructive"145 may still be apt, other vantage points may inject greater complexity and granularity and, in so doing, persuasively frame alternative characterizations of judicial campaign contributions that fall somewhere between positions staked out by Professors Shepherd, on the one hand, and Hall on another. ${ }^{146}$

\section{From the Empirical to the Normative}

Broadening the empirical debate to include evidence of the potential influence of extra-legal factors on judicial outcomes from any campaign contributor (pro-, non-, or anti-business) might help deflect the debate from a focus on narrow empirical points to the more theoretical (and decidedly non-empirical) question about whether, in the context of campaign finance and free speech, judicial elections are different in kind from non-judicial elections and, as such, whether they warrant different legal treatment when it comes to campaign finance. ${ }^{147}$ Within this stilldeveloping normative debate, two factors deserve attention. One is that even if one concedes the empirical point that pro-business contributions do not have any monopolistic lock on helping secure favorable judicial outcomes, non-business judicial contributions' distinctive focus may engender a similarly distinctive level of influence. A second factor involves questions about whether legal doctrine, specifically laws

\footnotetext{
144 See, e.g., Michael S. Kang \& Joanna M. Shepherd, Partisanship in State Supreme Courts: The Empirical Relationship between Party Campaign Contributions and Judicial Decision Making, 44 J. LEGAL STUD. S161, S178 (2015) (observing Kang \& Shepherd note a similar limitation to their work as well).

145 See SHEPHERD, supra note 103, at 2.

146 Compare SHEPHERD, supra note 103, with HALL, supra note 20.

147 See King \& Shepherd, supra note 144, at S165 (observing that campaign spending has increased dramatically and with it judicial elections have grown more competitive).
} 
governing public election campaign contributions, should treat judicial elections differently than non-judicial elections.

2. Pro-Business Contributions Overwhelm Non- and Anti-Business Contributions

Even if one concedes that pro-, non-, and anti-business judicial campaign contributions all possess the ability to influence favorable judicial outcomes, it is plausible that the magnitude and nature of probusiness contributions make them comparatively more efficacious and, thus, more worrisome. Business interests and lawyers (and law firms) dominate financial contributions to state supreme court judges' election campaigns. ${ }^{148}$ Between 2000-09, business interests, broadly defined, contributed more than $\$ 62.6$ million, or thirty percent of all judicial campaign contributions. ${ }^{149}$ Lawyers and lobbyists (principally plaintiff lawyers and their agents) contributed \$59.3 million, or another twentyeight percent of total judicial campaign contributions. ${ }^{150}$ By contrast, political campaign contributions to judges from unions are a small fraction as compared to the donations from either business interests or lawyers and lobbyists. ${ }^{151}$

Not only do campaign contributions from business interests exceed those from all other discrete interest groups, but business interests' legal agendas are typically more focused and benefit from a clearer idea of which judicial candidates business interests wish to target. ${ }^{152}$ Legal (and political) agendas advanced by lawyers and lobbyists, by contrast, are typically far less focused and more diverse, reflecting the various interests of a wide range of clients. ${ }^{153}$

On balance, business interests, through their campaign contributions, are perhaps uniquely positioned to successfully exert influence of state supreme court judges, particularly when these judges are called upon to decide business cases. If so, pro-business contributions, as Kang and

\footnotetext{
148 See id. at S168-69 (discussing how campaign contributions from business interests result in state supreme court judges favoring business litigants across a range of cases).

149 See SHEPHERD, supra note 103, at 1-2.

150 See id.

151 Cf. David Pozen, The Irony of Judicial Elections, 108 COLUM. L. REV. 265, 306 (2008) (noting that unions are small but formidable contributors in the judicial election process).

152 See id. at 297 (stating that contributions from business interests are often more substantial because these entities have more resources). See also id. at 306 (noting that businesses have very narrow litigation interests, and thus, judicial candidates give deference to these interests when businesses contribute to candidates judicial campaigns).

153 Cf. id. at 321 (discussing how lobbyists seeking judicial reform often advance stakeholder interests).
} 
Shepherd emphasize, may indeed pose a special threat to a collective goal for fair and impartial justice.

3. When it Comes to the First Amendment Are Judicial Elections Simply Different Than Other Elections?

Arguments abound about whether the judicial and traditional political electoral contexts differ enough to warrant treating the judicial campaign finance context differently than the non-judicial campaign finance context. ${ }^{154}$ Hall, for example, argues that whatever differences might exist they are insufficient to justify different legal treatment for the judicial and non-judicial elections when it comes to campaign finance. ${ }^{155}$ Others, however, emphasize the differences between judicial and nonjudicial elections and call for different campaign finance rules. ${ }^{156}$ Professor Shepherd, for example, argues that judicial campaigns are particularly vulnerable to distortion (and implicitly distinct from nonjudicial elections) due to pro-business campaign contributions' unique role in judicial elections. ${ }^{157}$

Others share Kang and Shepherd's conclusion but not their reasoning. Professor Sample, for example, emphasizes the public's different democratic expectations for the courts and legislative branches and concludes that these differing expectations justify treating judicial and legislative campaign finance with different legal rules. ${ }^{158}$ Professor Smith similarly dwells on differences between the judicial and legislative branches and notes that judicial elections can involve spending by "specific litigants" or "specific cases" despite a public commitment to an "impartial adjudicator. ${ }^{159}$ Smith contrasts the judicial context with the legislative where, he notes, the public expects legislators to "(generally, at

\footnotetext{
154 See Kang \& Shepherd, supra note 144, at S164 (contrasting how reformers desired to insulate judges from political and other pressures because judges were appointed to restrain both the executive and legislative branches of government, however, a majority of states adopted judicial elections).

155 See generally HALL, supra note 20.

156 See Kang \& Shepherd, supra note 144, at S176-78 (arguing that the rules for judicial and non-judicial elections should differ because ideology and campaign contributions heavily influence judicial decision-making).

157 See id. at S167 (discussing how campaign contributions from business interests result in state supreme court justices favoring business litigants across a range of cases).

158 See Sample, supra note 21, at 756-57 (opining that campaign contributions in judicial elections should be treated differently than campaign contributions in other elections).

159 See Adam Liptak et al., Caperton and the Courts: Did the Floodgates Open?, 18 N.Y.U. J. LEGIS. \& PUB. POL'Y 481, 496 (2015) (stating that judicial elections differ from legislative elections in that they focus on impartial adjudicators making decisions for specific litigants and specific cases unlike legislative elections where the decisions of legislatures are guided by what voters want).
} 
least) achieve the goals that the people who elected them wanted them to do." 160

Apart from scholars' perspectives, even some Supreme Court justices appear to tilt in this direction. Writing for the Court in Williams-Yulee $v$. Florida Bar, Chief Justice Roberts wrote that: "[j]udges are not politicians, even when they come to the bench by way of the ballot."161 Consequently, in a 5-4 decision, the Court upheld a restriction on election speech and fundraising for elected judges that would be "obviously" unconstitutional if applied to other candidates for elected public office. ${ }^{162}$ However, the Court's Williams-Yulee decision stands quite uneasily with the Court's prior decision in White which struck down a Minnesota law prohibiting state judicial candidates from making public statements concerning disputed legal or political issues incident to judicial campaigns. ${ }^{163}$

Somewhat lost in the debate is the possible analytical purchase of a distinction between using judicial campaign contributions to "buy" a judicial vote as opposed to a judicial philosophy or general outlook. Again, all surely agree that a campaign contribution that, quite literally, pre-secures a specific judicial vote in a particular case-or even creates an objectively unacceptable impression of judicial impropriety or bias - as the Court's decision in Caperton suggests, requires judicial recusal. ${ }^{164}$

4. Efforts to Purchase a Judicial Philosophy Rather Than a Judicial Outcome

More difficult, however, are judicial campaign contributions that do not seek to pre-secure a specific judicial outcome in particular case in the future but, instead, seek to promote a judicial philosophy, theory, or outlook. If judicial campaign contributions in state elections simply reflect support for a particular or general judicial philosophy, they quickly begin to resemble the (albeit indirect) role that campaign contributions to presidential candidates perform in federal election context.

While constitutional structure provides layers of separation between the electorate and a federal judge or Supreme Court Justice's appointment, few serious observers contest the role that politics plays when it comes to the selection of Article III judges and Justices. Indeed, in many ways our constitutional structure (to say nothing of political accountability) is

\footnotetext{
160 See id.

161 135 S. Ct. 1656, 1662 (2015).

$162 \quad I d$.

163 See Republican Party of Minn. v. White, 122 S. Ct. 2528, 2546 (2002) (holding that it is impermissible for states to regulate or restrain candidate speech based on its content).

164 Cf. Pozen, supra note 151, at 303 (suggesting that the recusal system should be more rigorous).
} 
designed to afford politics some role. 165 Once one concedes, either as a descriptive or normative (or both) matter, politics' role in the selection of federal judges, it logically follows that campaign contributions exert some influence, even if indirect.

While the academic literature is festooned with research illustrating the role of politics, particularly presidential politics, in federal judicial appointments, ${ }^{166}$ a brief description of two recent (and still-evolving) examples deserve brief mention. ${ }^{167}$ First, Justice Scalia's recent death presaged a political firestorm fueled by President Obama's decision to appoint Judge Merrick Garland to fill the vacant Supreme Court seat. ${ }^{168}$ (Now-former) President Obama's status as a lame-duck, Senate Majority Leader Mitch McConnelly's assertion that the Senate would simply not process any Supreme Court nominations so close to a presidential election, and Democratic presidential nominee Hillary Clinton's refusal to commit to re-appointing Judge Garland if she assumed the presidency contributed to the political intrigue. ${ }^{169}$ As Professor Maltz recently noted, the Garland nomination serves "as a graphic reminder of the influence of presidential politics on the evolution of constitutional doctrine." 170

Judge Garland's nomination by a lame-duck president within one year of a contested presidential election only heighted the electorate's attention to one likely outcome of the 2016 presidential election: [ $t$ ] he

\footnotetext{
165 See $i d$. (identifying various democratic benefits flowing from voters directly selecting state judges).

166 See Terri Peretti, In Defense of A POlitical Court 122 (1999) (explaining how presidents can gauge future judicial performance by carefully evaluating the political views of potential nominees); JOHN MALTESE, THE SELLING OF SUPREME COURT NOMINEES 4 (1995) (stating that the Senate has the authority to either confirm or reject presidential judicial nominees); STEPHEN CARTER, THE CONFIRMATION Mess: CleANing UP THE Federal APPOINTMENTS PROCESS 70 (1994) (analyzing how the current process of selecting Supreme Court Justices has become heavily political, which starkly contrasts how executive administrations before the 1980s selected potential Justices).

167 See supra notes 37-44 and accompanying text (describing how presidential politics heavily influence the nomination and appointment of Supreme Court Justices).

168 See Jonathan Adler, The Real Reason President Obama Won't Recess-Appoint Merrick Garland to the Supreme Court, WASH. POST, (Dec. 29, 2016), https:/ / www.washingtonpost.com/news/volokh-conspiracy/wp/2016/12/29/the-realreason-president-obama-wont-recess-appoint-merrick-garland-to-the-supreme-court/?utm _term=.8be1cf3660b8 [https://perma.cc/X7VB-5ZWY] (discussing how President Obama nominated Judge Merrick Garland to fill the late Justice Scalia's Supreme Court seat).

169 See id. (stating that the Senate is not constitutionally obligated to consider nominees appointed by the president).

170 Earl Maltz, The 2016 Election and the Future of Constitutional Law: The Lessons of 1968, 43 Hastings CONST. L.Q. 735, 735 (2016). But see Jeffrey J. Rachlinski et al., Judicial Politics and Decisionmaking: A New Approach, 70 VAND. L. REV. 2051, 2051 (2017) (experimental evidence suggesting that judges are not "politicians in robes").
} 
guarantee of one Supreme Court nomination and the not-implausible opportunity for additional nominations. ${ }^{171}$

And this latter observation leads to a second (albeit related) example. ${ }^{172}$ During the recent presidential campaign, then-candidate Trump publicly released two separate lists of individuals (totaling twentyone) whom he proclaimed during a televised presidential candidate debate he would consider nominating to the United States Supreme Court. ${ }^{173}$ Given the perception that the next U.S. president would likely be in a position to fill at least one seat (by definition) and, more probably, two or more seats, and that the next president would likely have a significant influence on the development of future U.S. law, as Professor Kidd et al. note: " [i]t is not surprising that Republicans wanted assurances that their nominee would nominate someone whose jurisprudence would match that of Scalia." 174 That is to say, then-candidate Trump (as well as his opponent, Secretary Clinton), took pains to inform the electorate throughout their campaigns about the "type" of judges and Justices they planned to nominate if elected. ${ }^{175}$ Moreover, both campaigns overtly ran campaign ads (negative and positive) and sought (and received) campaign contributions expressly over the issue of their approach toward judicial selections. ${ }^{176}$ Finally, not only did the two main presidential candidates perceive (almost assuredly correctly) the need for (or strategic political advantage of) discussing with the electorate what they would look for in the potential judicial nominees, but the mainstream media

171 See id. at 736 (inferring that the president's nomination extends beyond simply appointing one Justice because both Justice Breyer and Justice Ginsburg are approaching the age of retirement).

172 See infra notes 165-71 and accompanying text (suggesting that the 2016 presidential election results would influence the judiciary for years to come because the next president would likely appoint multiple Justices to the Supreme Court).

173 See Ed Whelan, Trump's Supreme Court Candidates, NAT'L REV. (Nov. 9, 2016), www.nationalreview.com/node/442036/print [https://perma.cc/PQ2D-2T4W] (listing president-elect Trump's twenty-one potential Supreme Court nominees).

174 See Maltz, supra note 170 (discussing why a democratic president would choose a nominee who would side with Justices Breyer, Ginsburg, Sotomayor, and Kagan, whereas a republican president would choose a nominee who would side with Justices Roberts, Thomas, Alito, and Kennedy for years to come).

175 See Jonathan Adler, How Scalia-esque Will Donald Trump's Supreme Court Nominee Be?, WASH. POST (Jan. 26, 2017), https:/ / www.washingtonpost.com/news/volokh-conspiracy/ wp/2017/01/26/how-scalia-esque-will-donald-trumps-supreme-court-nominee-be/?utm_ term=.7331ad04d232 [https://perma.cc/2P8F-F3M2] (discussing president-elect Trump's plan to appoint judges very much in the mold of Justice Scalia).

176 Cf. NANCY SCHERER, SCORING POINTS: POLITICIANS, ACTIVISTS, AND THE LOWER FEDERAL COURT APPOINTMENT PROCESS 174 (Stanford Univ. Press 2005) (arguing that presidential candidates have historically made the selection of justices and judges a campaign issue). 
reinforced the perception that the candidates' approaches toward judicial nominations were a legitimate and, indeed, important campaign issue. ${ }^{177}$

Very few at the time voiced any concerns with the presidential candidates' open, consistent, and persistent discussion during the campaign of what they would "look for" in their judicial nominees. ${ }^{178}$ If anything, the opposite was the case. ${ }^{179}$ That is, the candidates, media, and, likely, a sizable portion of the electorate, felt that such discussions were an important part of the presidential campaign. ${ }^{180}$ To be sure, what happened during the most recent presidential election cycle (and similar to many prior election cycles) involved action by those seeking positions in the executive branch that possess the authority to nominate judges and Justices - rather than those who aspired to Article III commissions. ${ }^{181}$ This is, of course, an important distinction. ${ }^{182}$ Distinction aside, however, one question that endures is whether this constitutes enough of a distinction to treat constitutional issues embedded in campaign finance laws differently for state judicial elections and federal elections. ${ }^{183}$

\section{CONCLUSION}

To the extent that any campaign contribution in judicial elections facilitates "buying" justice, an array of obvious problems arise. ${ }^{184}$ Because pro-, non-, and anti-business have demonstrated some (albeit slightly

177 Cf. Conor Friedersdorf, How a Hilary Clinton Presidency Would Affect the Supreme Court, ATLANTIC (Oct. 17, 2016), https://www.theatlantic.com/politics/archive/2016/10/how-ahillary-clinton-presidency-would-affect-the-supreme-court/501539/

[https://perma.cc/B2K9-K34U] (illustrating the importance of the Supreme Court nomination process). See also Jim DeMint, DeMint: Gorsuch is a Model for Future Judicial Nominations, THE HILL (Apr. 12, 2017), http://thehill.com/blogs/pundits-blog/thejudiciary/328518-demint-gorsuch-is-a-model-for-future-judicial-nominations

[https:// perma.cc/9383-9SWC] (inferring that president-elect Trump made his intentions to nominate a certain type of Supreme Court candidate known to voters well in advance).

178 See id. (interpreting that voters were satisfied because they were able to essentially vote for judicial candidates).

179 See id. (arguing that Supreme Court nominations are an important election issue).

180 Cf. Friedersdorf, supra note 177 (observing that discussions about Supreme Court nominations are necessary and important).

181 See Vicki Jackson, Packages of Judicial Independence: The Selection and Tenure of Article III Judges, 95 GEO. L.J. 965, 977 (2007).

182 See supra notes 37-44 and accompanying text (explaining how business and political party interests systematically influence judicial nominations, appointments, and decisionmaking).

183 Cf. Pozen, supra note 151, at 323 (suggesting that a change may be in the best interest of voters and the judiciary).

184 Cf. Pamela Karlan, Judicial Independences, 95 GEO. L.J. 1041, 1046 (2007) (discussing how judicial campaign contributions make judges beholden to the economic interests of donors and result in judges placing higher value on self-preservation as opposed to justice). 
different) systematic ability to influence judicial votes in business cases, then, at the very least, one less problem emerges. While this one less problem may not assuage some (or any) critics of pro-business campaign contributions in judicial elections, it nonetheless remains important to gain a full empirical picture before proceeding to contested normative and theoretical issues incident to assessing First Amendment protection for campaign contributions to judicial elections.

Additional empirical clarity on the relations between campaign contributions and judicial votes, while helpful, does not, however, reduce the difficulty of the related, and enduring, normative questions. To the extent that this issue uncovers an inevitable collision of important values, what remains is how best to reconcile these conflicting interests, ${ }^{185}$ and a single way to reconcile these conflicts may not exist. As Professor Karlan notes, "it is not categorically true that we want judges to ignore popular opinion and rely on their own consciences, or that we want to protect judges who ignore politically settled interpretations and rely on their own views of the law. Sometimes we do and sometimes we don't."186 Given this structural ambivalence, when it comes to narrower issues concerning judicial campaign contributions, the late-Justice Scalia likely got it right when he opined during the oral argument in White that: "[n]ow, [judicial elections] may be a very bad idea, but as long as [the First Amendment is] in your constitution, I find it hard to believe that it is a significant State interest of Minnesota to prevent [judicial] elections from being informed." 187

\footnotetext{
185 Cf. id. (concluding that solving the problems created by judicial campaigns can be solved by recapturing impartial justice and the rule of law).

186 Karlan, supra note 184, at 1048.

187 Brief for Petitioner at 45, Republican Party of Minn. V. White, 122 S. Ct. 2528 (2002) (No. 01-521)
} 
64 VALPARAISO UNIVERSITY LAWREVIEW [Vol.52

APPENDIX TABLE A1

\begin{tabular}{|c|c|c|c|}
\hline & Mean & s.d. & $(\mathrm{N})$ \\
\hline Pro-business judge vote & 0.50 & $(0.50)$ & 10,804 \\
\hline Anti-business judge vote & 0.50 & $(0.50)$ & 10,804 \\
\hline Business campaign contrib. (\% of ttl.) (raw) & 19.32 & $(22.59)$ & 10,607 \\
\hline $\begin{array}{l}\text { Non-business campaign contrib. (\% of ttl.) } \\
\text { (raw) }\end{array}$ & 59.15 & $(37.19)$ & 10,607 \\
\hline $\begin{array}{l}\text { Anti-business campaign contrib. (\% of ttl.) } \\
\text { (raw) }\end{array}$ & 3.54 & $(13.54)$ & 10,607 \\
\hline Total campaign contrib. (\$10K) (raw) & 40.91 & $(61.35)$ & 10,607 \\
\hline Non-partisan judicial election & 0.41 & $(0.49)$ & 16,083 \\
\hline Partisan election & 0.18 & $(0.39)$ & 16,083 \\
\hline Democrat justice & 0.42 & $(0.49)$ & 16,083 \\
\hline Republican justice & 0.46 & $(0.50)$ & 16,083 \\
\hline State tort climate & -0.13 & $(0.46)$ & 16,078 \\
\hline State citizen ideology & 55.93 & $(14.66)$ & 16,078 \\
\hline State elite ideology & 49.33 & (13.62) & 16,078 \\
\hline Business litigant was petitioner & 0.49 & $(0.50)$ & 16,083 \\
\hline Justice $w$ / in 2 years of term end & 0.24 & $(0.42)$ & 16,083 \\
\hline Case strength & -0.02 & $(43.13)$ & 7,112 \\
\hline
\end{tabular}

SOURCES: Follow the Money; Shepherd (2013) data sets. 